\title{
Buried Waste Integrated Demonstration Fiscal Year 1993 Close-Out Report
}

Katherine J. Owens

Reva A. Hyde

Published April 1994

Idaho National Engineering Laboratory

EG\&G Idaho, Inc.

Idaho Falls, Idaho 83415

Prepared for the

U.S. Department of Energy

Office of Environmental Restoration and Waste Management

Under DOE Idaho Operations Office

Contract DE-AC07-76ID01570

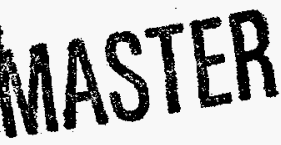

DISTRIBUTION OF THIS DOCUMENT IS UNLIMITED 


\section{DISCLAIMER}

This report was prepared as an account of work sponsored by an agency of the United States Government. Neither the United States Government nor any agency thereof, nor any of their employees, make any warranty, express or implied, or assumes any legal liability or responsibility for the accuracy, completeness, or usefulness of any information, apparatus, product, or process disclosed, or represents that its use would not infringe privately owned rights. Reference herein to any specific commercial product, process, or service by trade name, trademark, manufacturer, or otherwise does not necessarily constitute or imply its endorsement, recommendation, or favoring by the United States Government or any agency thereof. The views and opinions of authors expressed herein do not necessarily state or reflect those of the United States Government or any agency thereof. 


\section{DISCLAIMER}

Portions of this document may be illegible in electronic image products. Images are produced from the best available original document. 
Buried Waste Integrated Demonstration Fiscal Year 1993 Close-Out Report

EGG-WTD-11136

Prepared by

Keg. Querns

K. J. Owens, Project Manager

Reviewed by

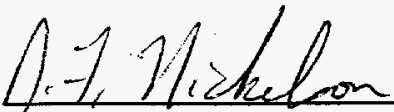

D. F. Nickelson, Principal Investigator

Approved by

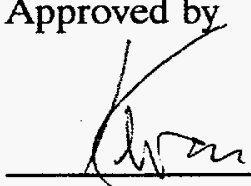

K. M. Kostelnik, Coordinator Buried Waste Integrated Demonstration
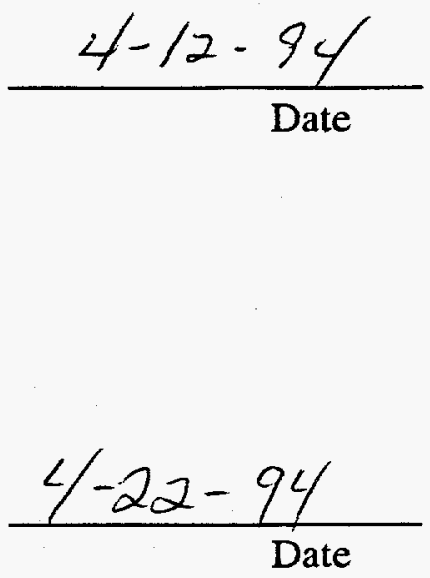


\section{ABSTRACT}

The Buried Waste Integrated Demonstration (BWID) supports the applied research, development, demonstration, and evaluation of a multitude of advanced technologies. These technologies are being integrated to form a comprehensive remediation system for the effective and efficient remediation of buried waste. These efforts are identified and coordinated in support of the U.S. Department of Energy Environmental Restoration and Waste Management needs and objectives. BWID works with universities and private industry to develop these technologies, which are being transferred to the private sector for use nationally and internationally. A public participation policy has been established to provide stakeholders with timely and accurate information and meaningful opportunities for involvement in the technology development and demonstration process. To accomplish this mission of identifying technological solutions for remediation deficiencies, the Office of Technology Development initiated BWID at the Idaho National Engineering Laboratory. This report summarizes the activities of the BWID program during FY-93. 



\section{SUMMARY}

This report summarizes the activities of the U.S. Department of Energy's (DOE's) Buried Waste Integrated Demonstration (BWID) for FY-93 activities. The mission of BWID is to support the development of a multitude of technologies for effective and efficient remediation of buried waste throughout the DOE complex. BWID evaluates, demonstrates, and validates technologies and transfers this information and equipment to DOE and private industry to support remediation planning and implementation.

BWID continues to perform research and evaluation of numerous technologies in the areas of characterization, retrieval, assay, contamination control, and treatment. In the characterization area, the focus is on improving sensitivity, range, response time, and cost of subsurface imaging. In buried waste retrieval, the focus is on precision, remote operations, productivity, and cost. In assay, research is focused on variety of species assayed, sensitivity, portability, response time, and cost. In contamination control, the focus is on fixing/stabilizing the source, controlling the spread of contaminants, compatibility with other operations, and cost. In the treatment area, the focus is on process robustness with regard to input waste diversity, effectiveness of the treatment, verification of the process, and cost.

BWID has obtained the support of universities, private industry, other national laboratories, and other Federal agencies in the development of these technologies. In FY-93, there were 17 industry/university partnerships, nine national laboratory partners, and partnerships with the U.S. Bureau of Mines, the U.S. Geological Survey, and Department of Defense.

The FY-93 budget for the BWID totaled $\$ 15.9 \mathrm{M}$, supported 42 Technical Task Plans (TTPs), and involved seven DOE field offices. Of the total budget, $\$ 1.9 \mathrm{M}$ was carried over from FY -92 , $\$ 10.5 \mathrm{M}$ was allocated at the beginning of FY-93, and $\$ 3.5 \mathrm{M}$ was allocated late in the fourth quarter of FY-93. These fourth-quarter monies were used for capital equipment purchases and the placement of subcontracts for work to be completed in FY-94. As a result of the fourth-quarter funding 12 new TTPs were added to the BWID FY-93 program. Of the $\$ 10.5 \mathrm{M}, 72 \%$ or $\$ 7.6 \mathrm{M}$ of the funding was associated with the DOE Idaho Operations Office. Of the $\$ 7.6 \mathrm{M}$, approximately $\$ 1.8 \mathrm{M}$ or $24 \%$ was subcontracted to the private sector, universities, or other Federal agencies. Of the $\$ 3.9 \mathrm{M}$ going to other DOE operations offices, $\$ 580 \mathrm{~K}$ or $15 \%$ was subcontracted to the private sector or universities. Private sector and university participation for FY-92 activities carried over into FY-93 was reported in the BWID FY-92 Closeout Report (EGG-WTD-10612). Private sector and university involvement for the FY-93 4th quarter activities will be reported in the BWID FY-94 Closeout Report.

BWID demonstrated and evaluated a number of technologies in FY-93. These demonstrations included characterization, retrieval, contamination control, and treatment activities. BWID placed increased emphasis on passing these technologies to private industries so that they could respond to requests to remediate specific waste sites in the future.

In the characterization area, the manual Rapid Geophysical Surveyor (RGS) demonstrated its technical value by performing geophysical surveys 30-300 times faster than hand-held instrument surveys and for a cost of 25 cents versus $\$ 5$ per data point. The RGS was developed for less than 
\$200K. The technology has been implemented by ER/WM organizations at the Idaho National Engineering Laboratory (INEL) and Los Alamos National Laboratory (LANL).

The Rapid TRU Monitoring Laboratory (RTML) mobile laboratory can be set up at a waste excavation site to continuously monitor airborne transuranic (TRU) contamination and rapidly analyze soil, smear, and air filter samples for TRU isotopes and fission and activation products. A conventional fixed laboratory with radiochemists can analyze several samples per day for $\$ 200-\$ 300$ per sample. In contrast, the RTML analyzes samples in less than one hour at $\mathrm{pCi} / \mathrm{g}$ levels for about $\$ 30$ per sample. The RTML is planned for implementation at the INEL and Hanford.

The Remote Characterization System (RCS) is a small, remotely controlled, wheeled vehicle that moves over a waste disposal site and transmits multiple sensor signals to a base station. The sensor array includes a magnetometer, photo ionization detector, radiation detector, electromagnetic induction detector, and ground penetrating radar. Other sensors may be added to accommodate different waste stream situations. With its ability to simultaneously deliver several kinds of sensors, the RCS shortens waste site characterization time and personnel are not exposed to hazardous conditions.

The Tensor Magnetic Gradiometer (TMG) is a joint development program. The TMG is an array of four triaxial ringcore fluxgate magnetometers fabricated by the U.S. Geological Survey. It measures the three magnetic field vectors and locates small isolated magnetic objects with only a few measurements. This omni-directional gradient information permits a simple quantitative interpretation from a single station.

In the technology area of retrieval, a retrieval demonstration was performed to determine the effectiveness of full-scale commercially available excavation equipment and end-effectors. This demonstration proved that standard excavation equipment can accomplish buried waste retrieval. Future work will investigate remotizing standard excavation equipment and integrating retrieval with characterization, contamination control, and conveyance.

The Remote Excavation System (RES) is a small, remotely controlled excavation vehicle that was tested for use in soil skimming and waste excavation. The RES incorporates advanced telerobotic and robotic excavation technologies, and is equipped with a front-end loader, backhoe, and electronics for control and positioning. Since precise control is required to excavate buried waste, the system was tested for cut precision, amount of dust generated (potential for contamination spread), speed of operation, and response of the robotic controls. The video subsystem, positioning equipment, and radio frequency link to the control station were also tested. All systems tested within required limits, and the RES will be used at Oak Ridge National Laboratory (ORNL) for buried waste retrieval.

In the contamination control area, the Contamination Control Unit (CCU) is a trailer-mounted system developed to control dust generated during buried waste excavation and retrieval. The system can dispense dust control products, including chemical soil fixants and water mist $100 \mathrm{ft}$ from the trailer. The nuclear grade vacuum system removes dust and soil debris from equipment, assisting in decontamination. Following BWID testing, this unit was used by the Environmental Restoration Program at Hanford for a retrieval treatability study. The unit was also used by the INEL Environmental Restoration Program during a capping action at EBR-1 in which Wendon dust 
suppressant was sprayed on a contaminated soil site of about 1.5 acres. Fernald has expressed an interest in using the unit to supply contamination control during some retrieval actions.

For the fixation of soil surface contamination studies, several dust suppressants were evaluated for their ability to control wind-blown contaminated soil from excavation and cleanup sites. The tests showed that natural polysaccharides are generally economically favorable to soluble matrix and can be easily broken down during subsequent soil treatment processes.

The objective of the overburden removal project was to demonstrate that overburden soil can be removed with precision and accuracy, fugitive dust can be controlled, and that sensors can warn the operator of nearby radioactive and hazardous conditions. The Caterpillar excavator used in the demonstration was fitted with a specially designed end-effector, vacuum system, and mounts for radiation sensors. During the demonstration conducted by Sonsub, Inc., the excavator functioned with a cut precision of about \pm 0.57 in., and average cut accuracy of only -0.08 in., or 0.08 in. below target depth. The excavator removed soil at an average rate of $11.6 \mathrm{yd}^{3} / \mathrm{hr}$, which exceeded requirements.

The electrostatic curtain addresses the problem of containing airborne dust contaminated with plutonium-239 $\left({ }^{239} \mathrm{Pu}\right)$ and americium-241 $\left({ }^{241} \mathrm{Am}\right)$. The electrostatic curtain uses grounded conducting plates upstream of high efficiency particulate air (HEPA) filters to neutralize charged dust particles. Monitoring equipment measures how much contaminated dust is removed from the air stream. Engineering-scale tests were conducted resulting in design specifications for $98 \%$ removal.

The dig-face characterization project is developing and testing a multi-sensor system to collect detailed characterization data and identify buried hazards in the dig-face as they are exposed during excavation. This ongoing project is expected to allow a safe-step remediation approach (i.e., alternately characterize, dig, characterize, dig, in a safe increments of the subsurface). The system consists of a remote gantry delivery system, geophysical chemical and radiological sensors, and a data interpretation subsystem.

In the treatment area, the ice electrode project used a novel approach to removing heavy metals from solutions. Bench-scale tests of this experimental technology showed that heavy metal contaminants in solution can be captured in an ice coating on a metal electrode, then recovered by allowing the ice to melt. Metals tested included copper, silver, zinc, cobalt, cadmium, lead, and chromium. Preliminary work with metals that do not electro-deposit on conventional electrodes, such as uranium and tungsten, suggests that oxides of such metals can be recovered at an ice electrode. An ice electrode reactor has been designed for pilot-scale testing.

The Graphite DC Plasma Arc Melter is an advanced DC graphite electrode plasma torch and furnace being tested for treating waste-containing solids, liquids, and off-gas streams, and for removing metals from the glass phase. The engineering-scale Màrk I furnace was demonstrated, and design improvements were incorporated into a Mark II furnace. The Mark II furnace has a unique coaxial graphite electrode, designed by Electro-Pyrolysis, Inc., that can be operated in the transferred or nontransferred mode. Diagnostic instruments are also being developed to support this ongoing project, which could be used to treat contaminated soil/waste removed from a buried waste site. The Mark II furnace is installed at the Massachusetts Institute of Technology and will begin testing in FY-94. 
The arc melter vitrification project is an extension of an in-progress Bureau of Mines and American Society of Mechanical Engineers (ASME) demonstration. This project will evaluate the applicability of a small commercial-scale arc melter to treat mixed TRU-contaminated wastes and buried or stored soils. Experiments are being coordinated with the DC Plasma Arc Melter project. Since many private sector companies are members of the ASME test consortium, cooperative agreements with industrial partners are being sought to expand the scope and speed completion of the demonstration project.

BWID has established a public participation policy with the goal of providing stakeholders with timely and accurate information and meaningful opportunities for involvement in the technology development and demonstration process. During 1993, presentations were made to civic, educational, and technical groups; displays and posters were viewed nationally; regular media contacts were established; and video teleconferences were held to enhance communication.

In FY-93 an integrated demonstration of five BWID-sponsored technologies took place at the INEL Cold Test Pit, located at the Radioactive Waste Management Complex. This integrated demonstration included the Remote Characterization System, Remote Excavation System, Rapid Geophysical Surveyor, Contamination Control Unit, and the Rapid TRU Monitoring Laboratory.

BWID sponsored a Technology Exhibition and Equipment Display in Idaho Falls, July 29, 1993, featuring the technologies involved with the integrated demonstration. The exhibition provided a forum to enhance the interaction between public and private sectors. There were 202 participants, including 43 representatives from industry, 5 representatives from academia, 15 participants from DOE EM-40 and EM-50, 126 participants from national laboratory contractors, and 13 participants from other government agencies.

As a result of the FY-93 integrated demonstration and BWID's public involvement activities, several technology transfers were implemented. A license has been approved for the inventors of the Rapid Geophysical Surveyor and they have formed a company to market the technology. A patent is pending for the Rapid Monitoring Laboratory and a company from Washington state has expressed an interest in marketing the unit. A patent is pending on the Contamination Control Unit and a private firm from Ohio has expressed an interest in marketing the unit. 


\section{CONTENTS}

ABSTRACT $\ldots \ldots \ldots \ldots \ldots \ldots \ldots \ldots \ldots \ldots \ldots \ldots \ldots \ldots \ldots \ldots \ldots \ldots \ldots \ldots \ldots \ldots \ldots$ iii

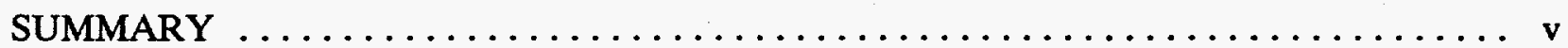

ACRONYMS $\ldots \ldots \ldots \ldots \ldots \ldots \ldots \ldots \ldots \ldots \ldots \ldots \ldots \ldots \ldots \ldots \ldots \ldots \ldots \ldots \ldots \ldots \ldots \ldots$

1. INTRODUCTION $\ldots \ldots \ldots \ldots \ldots \ldots \ldots \ldots \ldots \ldots \ldots \ldots \ldots \ldots \ldots \ldots \ldots \ldots \ldots \ldots$

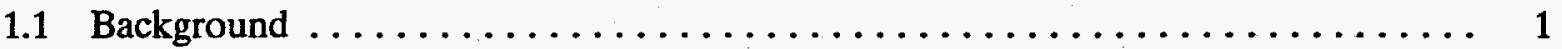

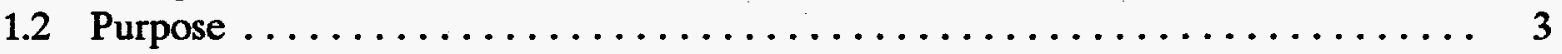

2. MANAGEMENT APPROACH $\ldots \ldots \ldots \ldots \ldots \ldots \ldots \ldots \ldots \ldots \ldots \ldots \ldots$

3. TECHNICAL ACCOMPLISHMENTS $\ldots \ldots \ldots \ldots \ldots \ldots \ldots \ldots \ldots \ldots$

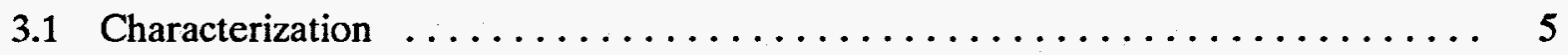

3.1.1 Improved TRU Waste Assay (CTEN)-AL132012 . . . . . . . . . . 5

3.1.2 Nonintrusive Sensing of Environmentally Important

Objects-AL911201 ...................... 5

3.1.3 Electrothermal Hollow Cathode Discharge SpectrometryCH121201 ............................... 8

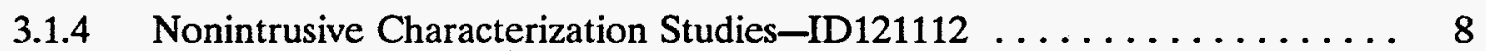

3.1.5 Radiological and Hazardous Materials Measurement System-ID121212 . . . . . . . . . . . . . . . . . . 9

3.1.6 Field Demonstration of Characterization Technologies-

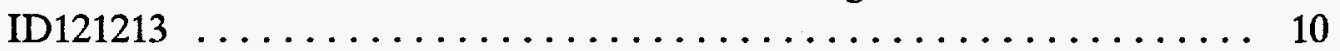

3.1.7 BWID Dig-Face Characterization-ID132003 ............. 11

3.1.8 Electromagnetic Imaging as Applied to Mapping and

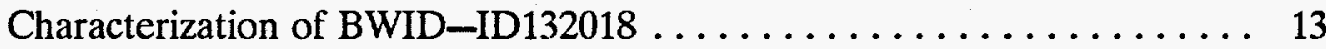

3.1.9 Geophysical Workshop-ID132019 ..................... 14

3.1.10 High-Speed Digital Radiography and Computed Tomography of Waste Drums-ID132020

3.1.11 Hazardous and Chemical Waste Separation at RWMC Excavation Sites-ID132021 . . . . . . . . . . . . . . . . . 15

3.1.12 EM Rapid Geophysical Surveyor-ID132024 . . . . . . . . . . . . 16

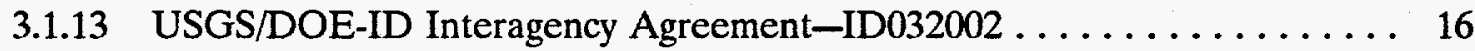

3.1.14 BWID Remote Characterization System-ID332001, AL232006, OR132013, RL332016, and SF232001 ................ 16

3.1.15 Active and Passive Computed Tomography Gamma Assay of Radioactive Waste-SF221209 . . . . . . . . . . . . . . . . . . . 19

3.2 Retrieval $\ldots \ldots \ldots \ldots \ldots \ldots \ldots \ldots \ldots \ldots \ldots \ldots \ldots \ldots \ldots \ldots \ldots \ldots$

3.2.1 Gas Contamination-AL021201 ................... 19 
3.2.2 Retrieval Demonstration-ID121203 . . . . . . . . . . . . . . 20

3.2.3 Retrieval Related Technologies-ID132007 ................. 22

3.2.4 Contamination Control-ID121210 ................... 26

3.2.5 Three-Dimensional Dynamic Graphic Simulation-ID132022 ........ 31

3.2.6 Multi-Axis Crane-ID332002 . . . . . . . . . . . . . . . 32

3.2.7 Remote Excavation System-ID332004, AL232007, RL332017,

OR132014, and SF232002 ....................... 33

3.2.8 Fixation of Soil Surface Contamination Using Natural

Polysaccharides-RL432002 ....................... 34

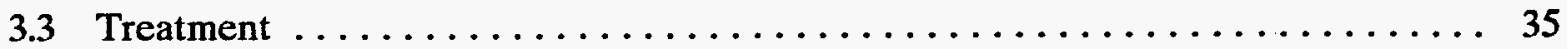

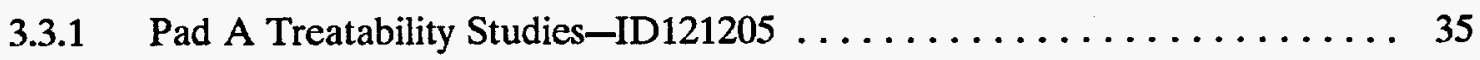

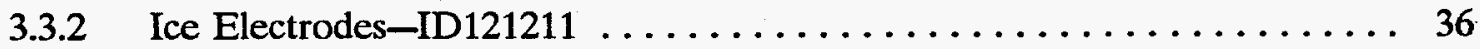

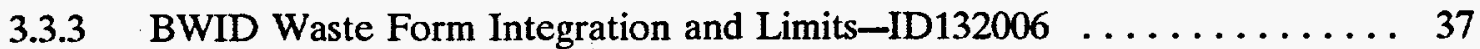

3.3.4 BWID Thermal Kinetics-ID132010 ................. 37

3.3.5 BWID Arc Melter Vitrification-ID132011 ................ 39

3.3.6 Butte Plasma Arc Furnace-PE021203 . . . . . . . . . . . . . 39

3.3.7 Graphite DC Arc Plasma Furnace-RL321211 .............. 40

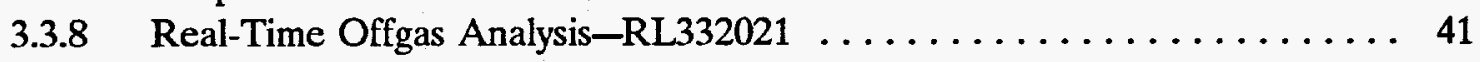

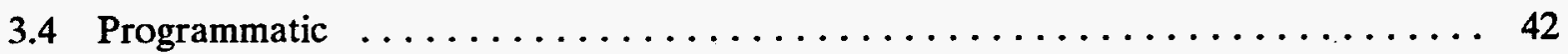

3.4.1 BWID Program Coordination-ID132008 ............... 42

3.4.2 BWID Technical and Academic Review Group-ID132015 . . . . . . 43

3.4.3 BWID/EM-40 Interface-ID132023 ................. 43

4. FINANCIAL ASSESSMENT $\ldots \ldots \ldots \ldots \ldots \ldots \ldots \ldots \ldots \ldots \ldots \ldots \ldots \ldots \ldots \ldots \ldots \ldots$

Appendix A-List of Buried Waste Integrated Demonstration FY-93 Report . . . . . . . A A-1

Appendix B-List of FY-93 Subcontractors (Private Industry, Universities, and Other Non-DOE Federal Agencies) $\ldots \ldots \ldots \ldots \ldots \ldots \ldots \ldots \ldots \ldots \ldots \ldots \ldots \ldots \ldots$ 


\section{ACRONYMS}

\begin{tabular}{|c|c|}
\hline A\&P CT & active and passive computed tomography \\
\hline ASME & American Society for Mechanical Engineers \\
\hline BWID & Buried Waste Integrated Demonstration \\
\hline CAM & continuous air monitor \\
\hline CAS & chemical assay system \\
\hline CAT & computer automated tomography \\
\hline $\mathrm{CCU}$ & Contamination Control Unit \\
\hline CERCLA & Comprehensive Environmental Response, Compensation, and Liability Act \\
\hline CRADA & Cooperative Research and Development Agreement \\
\hline CT & computed tomography \\
\hline CTEN & combined thermal/epithermal neutron \\
\hline DOE & U.S. Department of Energy \\
\hline DOE-ID & U.S. Department of Energy Idaho Operations Office \\
\hline DR & digital radiography \\
\hline EM & electromagnetic \\
\hline EM-30 & DOE Headquarters Waste Management \\
\hline EM-40 & DOE Headquarters Environmental Restoration \\
\hline EM-50 & DOE Headquarters Technology Development \\
\hline EPA & U.S. Environmental Protection Agency \\
\hline ER & Environmental Restoration \\
\hline FDEM & frequency domain electromagnetics \\
\hline FY & fiscal year \\
\hline GPR & ground penetrating radar \\
\hline GPS & global positioning system \\
\hline HEPA & high efficiency particulate air \\
\hline IDC & Integrated Demonstration Coordinator \\
\hline INEL & Idaho National Engineering Laboratory \\
\hline ISV & in situ vitrification \\
\hline LINAC & linear accelerator \\
\hline LLNL & Lawrence Livermore National Laboratory \\
\hline LLW & low-level radioactive waste \\
\hline LSV & low signature vehicle \\
\hline MIT & Massachusetts Institute of Technology \\
\hline ORNL & Oak Ridge National Laboratory \\
\hline PCF & plasma centrifugal furnace \\
\hline PI & Principal Investigator \\
\hline PNL & Pacific Northwest Laboratory \\
\hline RCRA & Resource Conservation and Recovery Act \\
\hline RCS & Remote Characterization System \\
\hline RES & Remote Excavation System \\
\hline RGS & Rapid Geophysical Surveyor \\
\hline RTML & Rapid Transuranic Monitoring Laboratory \\
\hline RWMC & Radioactive Waste Management Complex \\
\hline SEM & scanning electron microscope \\
\hline TARG & Technical and Academic Review Group \\
\hline
\end{tabular}


TDEM time domain electromagnetics

TL Technical Liaison

TMG

Tensor Magnetic Gradiometer

TRA

TRU

Test Reactor Area

TTP

transuranic

USGS

Technical Task Plan

U.S. Geological Survey

WHC

Westinghouse Hanford Company

WM

Waste Management 


\section{Buried Waste Integrated Demonstration Fiscal Year 1993 Close-Out Report}

\section{INTRODUCTION}

\subsection{Background}

The amount of buried waste located throughout the U.S. Department of Energy (DOE) complex as of 1990 is estimated at approximately 3.1 million $\mathrm{m}^{3}$ (DOE Complex Buried Waste Assessment, PNL-8390, January 1993). The DOE sites where this waste is predominantly located are Hanford, Savannah River, Idaho National Engineering Laboratory (INEL), Los Alamos, Oak Ridge (X-10), and Rocky Flats. The wastes at these various sites have been buried or stored in several types of structures, including trenches, pits, buildings, and storage pads.

Approximately half of all DOE buried waste was disposed of before 1970 in accordance with the regulations of that time. Disposal regulations at that time permitted the commingling of various types of waste [transuranic (TRU), low-level radioactive (LLW), and hazardous]. As a result, much of the buried waste throughout the DOE complex is presently believed to be contaminated with both hazardous and radioactive materials. DOE buried waste typically includes TRU-contaminated radioactive waste, LLW, hazardous waste per 40 CFR 261, greater-than-class-C waste per 10 CFR 61.55 , mixed TRU waste, and mixed LLW. Interstitial soils are also believed to be contaminated as a result of these disposal practices, which significantly increases the volume of materials requiring remediation.

Typical buried waste includes construction and demolition materials (lumber, concrete blocks, steel plates, etc.), laboratory equipment (hoods, desks, tubing, glassware, gloves, etc.), process equipment (heat exchangers, valves, ion exchange resins, high efficiency particulate air filters, etc.), maintenance equipment (hand tools, cranes, oils and greases, etc.), and decontamination materials (paper, rags, gloves, plastic bags).

The waste and site characteristics of the INEL Radioactive Waste Management Complex (RWMC) are generally representative of other DOE buried waste sites. Therefore, remediation technology demonstrations performed at the INEL will be transferable for potential applications at other DOE buried waste sites. Approximately 0.3 million $\mathrm{m}^{3}$ of waste is buried at RWMC. Various containers were used for the disposal of buried waste. Typical containers used for waste shipment included steel drums $(30,40$, and 55 gal), cardboard cartons, and wooden boxes (up to $105 \times 105 \times$

214 in.). Larger individual items were disposed of separately as loose trash. Degradation of the waste containers is believed to have resulted in contamination of the immediately surrounding soil. Estimates of contaminated soils at the INEL are in the order of 0.9 million $\mathrm{m}^{3}$.

In the past, incomplete records were kept, and as a result, the exact nature of the contamination is uncertain. Over the years, some of the waste-containing drums and boxes have breached, creating new problems. Some have potentially contaminated groundwater. 
These waste disposal sites must be remediated or cleaned up within the existing and evolving statutory and regulatory requirements. These requirements may include the Federal Facility Agreement and Consent Order; Comprehensive Environmental Response, Compensation, and Liability Act (CERCLA); Resource Conservation and Recovery Act (RCRA); and other interagency agreements with legally binding milestones.

Buried waste presents significant remediation challenges, particularly the waste buried prior to 1970. DOE is committed to remediating the problems that resulted from past disposal practices. In an effort to focus resources and address these opportunities, the Office of Technology Development has developed integrated programs and integrated demonstrations. The integrated program is the cost-effective mechanism that assembles a group of related technologies to evaluate their performance to solve a specific aspect of a waste management or environmental problem. The integrated demonstration is the cost-effective mechanism that assembles a group of related technologies to evaluate their performance individually or as a complete system in correcting waste management and environmental problems.

The INEL, which has a significant portion of the DOE TRU buried waste, has been chosen as the lead site for the Buried Waste Integrated Demonstration (BWID) to demonstrate emerging technologies that offer promising solutions to the problems associated with the remediation of buried waste. BWID addresses the difficult remediation problems associated with DOE complex-wide buried waste, particularly TRU-contaminated buried waste.

BWID focuses on the remedial technology application needs of Environmental Restoration and Waste Management (ER/WM). ER/WM sites from across the DOE complex are frequently assessed. Their needs define remedial technology areas where inadequate, marginal, or no technology exists, and the time frame available to provide input to the remedial decision processes. Technology development and demonstration proposals are solicited and evaluated by BWID to determine their potential to support the ER/WM applications. The time frame prior to ER/WM decision milestones is considered by BWID's window of opportunity for development of more cost-effective and efficient solutions for buried waste remediation needs closely ties into ER/WM scheduled milestones.

A detailed system analysis was initiated in FY-92 and is being used to identify and develop high-level systems for the remediation of buried wastes. The BWID system's approach defines the functions that need to be performed by remedial technologies. This approach encompasses the entire remediation process from characterization to postmonitoring. The development and demonstration of the technology is predicated on how a technology fits into the total remediation process. To address all of these technological issues, BWID has enlisted scientific expertise of individuals and groups from within the DOE complex as well as experts from universities, private industry, and the international community.

Technology development and demonstration activities sponsored by BWID are based on their potential contribution to the overall system as well as individual performance potential. These activities are guided by technical objectives that are derived from the performance needs of the system. During testing, technologies are evaluated against technology-specific performance objectives and high-level system objectives to assess both individual technology performance and impact on the overall system. 
Technology performance tests are conducted to evaluate a technology's performance relative to the technical objectives. The performance tests were valuable in obtaining technology specific data on a technology's effectiveness, implementability, and cost. BWID provides this information to potential end users such as ER/WM to assist them in remedial planning and feasibility studies. As technology data are infused into the ER/WM planning cycle, the probability that the technology will be of benefit to the remediation efforts is enhanced. In this manner, BWID technologies are being either considered for application or are in use by ER/WM. BWID has already contributed to remediation efforts at Hanford, Oak Ridge, INEL, and Los Alamos.

As technology development approaches the demonstration stage, BWID conducts demonstrations in an integrated fashion. This provides a cost-effective method to evaluate the performance of technologies in simulated real-life conditions. These demonstrations provide the opportunity to not only evaluate the individual performance of a technology, but also the performance of all or portions of the complete remediation system.

Technologies are evaluated against the technical objectives defined by the remediation system and ER/WM needs. Technology evaluations are conducted using guidance similar to the CERCLA Feasibility Study guidance for the detailed analysis of remedial alternatives and technology options. The use of technology evaluation criteria guidance as set forth by CERCLA enhances regulatory and stakeholder acceptance of demonstrated technologies. In FY-94, BWID will work with the U.S. Environmental Protection Agency (EPA), Region 10, in developing a uniform testing protocol to further enhance acceptance of BWID demonstrated technologies. Published BWID technology evaluation reports become reference sources for ER/WM decision analyses.

The goal of BWID is to determine the threshold of capability for emerging technologies. Technologies have been identified, screened for applicability to the identified needs and requirements, selected for demonstration, and evaluated based on prescribed performance objectives. This effort will determine implementability, effectiveness, potential schedule reduction, and cost savings associated with emerging technology to shape remediation plans and implementation of the environmental restoration of buried waste.

\subsection{Purpose}

The purpose of this document is to summarize the activities of the FY-93 BWID program. This summary is not intended to be an extended review of all activities but rather a highlight of significant technical accomplishments for each FY-93 BWID-sponsored Technical Task Plan (TTP). A financial summary of the entire program is also presented in Table 1. Supporting information, such as the reports produced and list of subcontractors, are included in Appendices A and B. 


\section{MANAGEMENT APPROACH}

To ensure that the project was managed in an efficient and effective manner, a BWID Program Office was organized at the INEL in FY-91. Management guidance was developed to implement a system that ensured successful deployment of technologies. This approach assumed the responsibility for facilities, operations, regulatory compliance, and public involvement activities by the BWID Program Office. Centralization of these activities resulted in a reduction in the cost of deployment and provided assurance that technologies would get to the field as planned. The BWID Program Office staff was established as an interdisciplinary team employing numerous quality improvement tools to ensure its effectiveness.

Early in development, it was recognized that effective communication and good project management were key in a successful BWID program. To ensure effective communication, frequent meetings were held between the U.S. Department of Energy Headquarters Program Manager, DOE Idaho Operations Office (DOE-ID) Technical Program Officer, and BWID Integrated Demonstration Coordinator (IDC). Additional communication mechanisms were identified to enhance communication between the Program Office and the ER/WM customer, and between the Program Office and the Principal Investigators (PIs).

A new management structure will be implemented for FY-94. The IDC will be supported by a Systems Integration Program Manager and a Technology Deployment Manager. In addition, a new role called a Technical Liaison (TL) will be added to the program team for FY-94 and become the direct link between the PIs and Program Office. Six TLs will be identified to represent PIs associated with a technology that falls into one of the following technical categories: Geophysical Characterization, Nondestructive Assay, Treatment, Retrieval, and Contain/Stabilize. In addition to the new TL role, a new Technical and Academic Review Group (TARG) is being formed consisting of experts from specific technical areas pertinent to BWID. The members will come from organizations throughout private industry and the academic community. This new group will provide the BWID program with independent technology peer reviews of current and proposed technologies. 


\section{TECHNICAL ACCOMPLISHMENTS}

Three major technical areas (characterization, retrieval, and treatment) and one programmatic area were involved with the FY-93 BWID program. While the technical areas were specific for technology development and demonstration, the programmatic activities provided a more detailed assessment of the DOE complex buried waste problem as well as systematic approaches for satisfying technological deficiencies. A summary of accomplishments for each TTP is provided by technical area in the following sections.

\subsection{Characterization}

\subsubsection{Improved TRU Waste Assay (CTEN)-AL132012}

Funding for this TTP was received late in the fourth quarter of FY-93. Work was initiated, but the majority of the work will be completed in FY-94.

The objective of this TTP is to develop a system to assay TRU/fissile contents of waste drums using both epithermal and thermal neutron interrogation to reduce inaccuracies caused by self shielding. A fully operational combined thermal/epithermal neutron (CTEN) device would be expected to perform all the functions of existing differential dieaway technique (DDT) passive-active neutron devices with the added capability of identifying and assaying lumps of material.

Major tasks included in this TTP are:

- Complete Monte Carlo studies

- Complete all design drawings

- Complete fabrication

- Complete system software.

Technology Transfer

Though primary applications are in the waste field, use by fuel fabricator, international safeguard agencies, and Department of Defense special nuclear material monitoring may result in additional partners and deployment, or markets. The research will be disclosed through professional journals and presentations at technical conferences to assist transfer of this technology to both private sector, contractors, and other government agencies.

\subsubsection{Nonintrusive Sensing of Environmentally Important Objects_AL911201}

This activity was initiated in FY-92 and is continuing through FY-94. This program consists of four subtasks in support of BWID as described below:

\section{Site Characterization and Object Location Using a Tensor Magnetic Gradiometer}

The objective of this subtask is to develop an improved system for nonintrusive site characterization through the measurement and interpretation of the magnetic gradient tensor. This 
technique provides more information about buried magnetic objects than measurements of a single component of the magnetic field or its gradient. Thus, a field system that measures the magnetic gradient tensor will significantly improve survey efficiency and quantitative interpretation.

The construction of a four element tensor gradiometer array consisting of high sensitivity, triaxial, ringcore fluxgate magnetometers located at the ends of a tetrahedral structure was completed by our joint participant, the U.S. Geological Survey (USGS). Static testing and calibration of the Tensor Magnetic Gradiometer (TMG) is planned for FY-94 along with a dipole mapping demonstration to exhibit the utility of the system.

\section{Accomplishments}

Static testing of the TMG is $60 \%$ complete with one half of the calibration tests and raw data acquired to demonstrate dipole tracking. Delays encountered in developing temperature compensation procedures have caused schedule slippage. A mobile demonstration of the technology at BWID in FY-94 is unlikely.

A Technology Preparedness and Status Report by D. D. Snyder was issued in November 1992 (see Appendix A).

\section{Three-Dimensional Site Characterization Using Broadband Electromagnetics}

Current broadband electromagnetic technologies and interpretation techniques used in mineral exploration will be adapted for detection and three-dimensional characterization of shallow targets. An extension of this program in FY-94 will evaluate new procedures and interpretation techniques heretofore unavailable.

The effectiveness of the time domain electromagnetics (TDEM) method for mapping DOE waste sites was demonstrated in FY-92 by delineating pit dimensions and locations. An extension of this TTP will provide for a modeling study and advanced interpretation of the existing data. Finally, specifications for an optimal TDEM system for waste mapping will be developed.

\section{Accomplishments}

A demonstration of TDEM system capabilities was performed in FY-93 but the utility of advanced interpretive techniques has yet to be determined. All objectives were met in FY-93 and are on schedule.

Two reports were issued by H. D. Mac Lean, Preliminary Field Results-Time Domain Electromagnetic (TDEM) Survey of Three Waste Burial Pits and INEL Radioactive Waste Management Complex, DOE/ID/12584-130 Vol. 1., was issued in January 1993 and Technology Preparedness and Status Report was issued November 1992 (see Appendix A). 


\section{Integrated Borehole Geophysical System for Contaminant Identification}

This subtask will demonstrate, test, and evaluate existing prompt fission neutron technology for characterizing fissile contaminants by observing thermal and epithermal neutron densities. Appropriate boreholes at BWID, or other DOE sites, will be used for field evaluations.

This subtask consists of five major activities:

- Upgrade logging system

- Develop modeling facility

- Perform modeling experiments

- Perform demonstrations

- Prepare reports.

\section{Accomplishments}

The field demonstration of the prompt fission neutron probe planned for BWID was canceled because an appropriate site was not available. Instead, the demonstration was successfully implemented at the Hanford Plutonium Cribs in September 1993.

Plans for this subtask to continue through FY-94 were altered when funds were withdrawn. By expediting the program, a successful demonstration was performed in FY-93, although time and funds did not permit report preparation.

\section{Electromagnetic Methods for Dig-Face Monitoring}

Induction electromagnetic (EM) sensors represent a method for mapping ground conductivity patterns that can reveal qualitative and quantitative information on subsurface materials. This particular application requires sensors designed to function from the dig-face gantry crane, and focus on objects at a distance of one meter. Consultation on the optimum design will be conducted with Professor A. Kaufman of the Colorado School of Mines, and system development accomplished at DOE Grand Junction Program Office during FY-94.

Initially, a commercially available Geonics EM-38 instrument is to be supplied for integration into the dig-face proof-of-principle package. A second objective is the assembly of an experimental induction EM system for evaluating sensor arrays and measurement parameters that have been optimized for the dig-face application.

\section{Accomplishments}

The proof-of-principle EM instrument was supplied to the dig-face characterization during FY-93. Testing of the custom design experimental EM system began in December 1993.

\section{Technology Transfer}

The TMG testing and mobile deployment will result in a proven concept that is ready for technology transfer. Vendors supplying the base instrumentation and equipment for the TMG, firms 
involved in buried waste cleanup, companies interested in locating buried objects such as mining interests and oil companies, and Department of Defense contractors locating buried unexploded ordnance provide some of the markets and interest in this concept. In addition to DOE, the U.S. Navy and USGS have been participants the project. The implementation and interaction of the data display hardware and software are of interest to both instrumentation manufacturers and software programmers. Disclosure of this research through professional journals and presentations at technical conferences will enhance transfer of this technology to a wider network of private sector contractors, who may be able to manufacture or enhance portions of the system of find applications beyond buried object location.

\subsubsection{Electrothermal Hollow Cathode Discharge Spectrometry-CH121201}

Funding for this TTP was received late in FY-92 and activities carried over into FY-93. This technology holds promise for the elemental and isotopic analysis of actinides. It is a technique that should require minimal samples sizes, should be relatively rapid (minutes for analysis), and requires instrumentation sufficiently compact to be easily housed in a site-based laboratory. The specific tasks carried over to FY-93 included the initial testing of the instrument, publication of the test results and support for Ames personnel to participate in BWID technical support group activities.

\section{Accomplishments}

Publication of test results in the report entitled In-Situ Monitoring of Actinides and Rare Earth Elements by Electrothermal Hollow Cathode Discharge Spectrometry by Sang C. Lee and M. C. Edelson, Ames Lab Report IS-5085, was released in December 1992.

\section{Technology Transfer}

This system could be used during retrieval actions to verify presence of hazardous materials and actinides in soils prior to return of the treated soils. Disclosure of this research through professional journals and presentations at technical conferences will ensure transfer of this technology to private sector contractors that may be performing waste site remediations.

\subsubsection{Nonintrusive Characterization Studies-1D121112}

This technology was initiated in FY-93 and will be completed in FY-94. The objective of this TTP was to perform a multidisciplinary assessment of existing underground radar survey and mineralogy data at the INEL and publish a final report on the dielectric properties and attenuations as a function of radar wave frequency. The successful integration of data sets procured through this TTP will lead to a better understanding of how geophysical methods can be applied to the characterization of buried waste sites.

The major task for this TTP is to review, approve, and publish final reports on existing radar surveys, mineralogy, and dielectric properties and attenuation. 


\section{Accomplishments}

Ground penetrating surveys were conducted at the INEL Cold Test Pit by the South Dakota School of Mines and Technology. Results were issued in a letter report entitled "Feasibility of Using Ground Probing Radar for Environmental Site Characterization: Preliminary Assessment" in March 1993 (see Appendix A).

The Ground-Probing Radar Planning Workshop was held in Idaho Falls on September 23, 1993. A draft document entitled Proceedings of the Ground-Probing Radar Planning Workshop was issued October 31, 1993.

\section{Technology Transfer}

No hardware or software was developed for this effort. All information obtained through these studies is contained in the report summarized in Appendix A.

\subsubsection{Radiological and Hazardous Materials Measurement System-ID121212}

The focus of this TTP was the continuation of work initiated in FY-92. However, FY-93 funding for this effort was not received until the fourth quarter of FY-93. Therefore, deliverables will not be completed until FY-94. The main objective of this TTP is to enhance waste assay capability through improved individual measurement capability and integrating results together. Specific objectives include:

- Improve sensitivity and accuracy for gamma assay, active neutron, and thermal neutron capture measurements

- Develop methods for integrating individual measurements for improved quantitative assays.

\section{Accomplishments}

In FY-92, a proton linear accelerator (LINAC) was installed at the Idaho State University physics laboratory. The LINAC is expected to provide significant improvement over the current state of the area measurement systems by improving measurement thresholds and production rates. Results of the LINAC will be documented in FY-94. In addition, performance and design specifications of the Radiological and Hazardous Measurement Monitoring System was completed in FY-92 and continuation of this work is expected to be completed in FY-94.

\section{Technology Transfer}

Several expressions of interest from industry with regard to Cooperative Research and Development Agreements (CRADAs) are being evaluated. The completed system is planned for implementation by the INEL Waste Management Program. Disclosure of this research through professional journals and presentations at technical conferences will ensure transfer of this technology to private sector contractors who may be performing waste site remediations. 


\subsubsection{Field Demonstration of Characterization Technologies-ID121213}

The focus of this TTP is the continuation of work initiated in FY-92. Of $\$ 440 \mathrm{~K}$ in carryover funds, $\$ 244 \mathrm{~K}$ was used for the TechniScan contract and $\$ 103 \mathrm{~K}$ was used to purchase new magnetometers for the Rapid Geophysical Surveyor (RGS). The remaining $\$ 93 \mathrm{~K}$ was used for data interpretation, report writing, and project management functions. FY-93 funding in the amount of $\$ 70 \mathrm{~K}$ provided the enhancement of the RGS with the installation of the cesium magnetometers and field demonstration of the system at the INEL Cold Test Pit.

Main objectives of this TTP are:

- Demonstrate imaging of buried objects in INEL soil with the three-dimensional scanner developed by TechniScan. The three-dimensional scanner is an inverse scattering ground penetrating radar (GPR) system producing quantitative, distortionless images analogous to a computer automated tomography (CAT) system. It is intended to generate images of objects in INEL soil.

- Design, construct, and demonstrate a device to quickly and inexpensively characterize buried waste sites by collecting high quality, dense sets of magnetic data.

\section{Accomplishments}

- TechniScan Contract

- TechniScan completed the development of a prototype three-dimensional scanner that will be ready to be tested in INEL soil in FY-94.

- $\quad$ Letter report entitled, First Inverse Scattering from Reflection Mode was issued in August 1993 (see Appendix A).

- $\quad$ RGS

- The RGS was successfully demonstrated at the Cold Test Pit and then used to scan buried waste at Pits 7 and 9 at RWMC and at Los Alamos National Laboratory. Straightforward interpretation principles were applied to the magnetic data, which provided reliable detection of all the isolated ferrous objects in the Cold Test Pit Characterization Cell, a general depiction of the Retrieval Cell, and an accurate definition of the overall waste pit. The RGS can collect spatially denser data sets than previously possible, thereby providing a much higher resolution picture of the buried waste site. The surveyor was developed for less than $\$ 200 \mathrm{~K}$.

- Informal report entitled, Rapid Geophysical Surveyor Final Report, EGG-WTD-10566, was issued in January 1993 (see Appendix A).

- Informal report entitled Test Plan for the Rapid Geophysical Surveyor, EGG-WTD10875, was issued in June 1993 (see Appendix A). 
- $\quad$ Final report entitled FY-93 Rapid Geophysical Surveyor Performance Tests was issued in August 6, 1993 (see Appendix A).

Test results show that the RGS data using the cesium magnetometers resolve anomalies in greater detail than exhibited by counterpart anomalies in the conventional data sets. Whereas the RGS collects 16-24 data points within the area of a typical small anomaly (or subpeak of a larger anomaly), conventional surveying produces only 1-2 data points. Small features, which are prevalent at sites containing waste buried at shallow depths, are fundamentally undersampled at conventional data spacings. The RGS magnetic data provide a clear record of subsurface changes compared with conventional magnetometers which cannot.

The RGS magnetic data provided reliable detection of isolated ferrous objects. The high data density developed through use of the RGS platform proved invaluable for distinguishing subtle anomaly features and for recognizing interference patterns in the magnetic data; these steps are crucial in interpreting object locations.

Based on manual depth interpretations of the RGS magnetic data and comparison with documented depths of buried objects, the RGS consistently provides depth estimates that are accurate to within 1 foot for shallow, isolated magnetic objects. Densely sampled data are crucial for adequately characterizing steep anomaly flanks produced by shallow magnetic objects as required to perform manual depth interpretation.

Repeated magnetic surveys during excavation show that a progressive increase in object resolution occurs as the distance between the sensors and the magnetic sources decreases. The main outcome from the excavation exercise strongly supports the idea of continuously collecting data during waste retrieval.

\section{Technology Transfer}

- TechniScan

A successful demonstration of this technology will enable TechniScan to market the system throughout the DOE system and in the larger waste field, including Superfund buried waste characterization and remediation projects. Companies interested in locating buried objects, such as mining interests and oil companies, and Department of Defense contractors locating buried unexploded ordnance also might use the technology.

- $\quad$ RGS

Disclosure of this research to private sector interests via technical journals and presentations at technical conferences are expected to initiate interest in RGS. A patent and licensing agreement are being sought by the inventors.

\subsubsection{BWID Dig-Face Characterization-1D132003}

The Dig-Face Characterization project is an integrated demonstration of multiple sensors that can be used as part of a retrieval effort. The dig-face characterization technology will allow 
continuous and continually improving monitoring and characterization of the site being remediated. The dig-face characterization technique is integrated into the remediation process itself. As retrieval progresses, sensor data interpretation skills improve by comparing interpreted data images with the retrieved targets.

This TTP had four major objectives:

- Develop several prototype sensors and test for potential use in a dig-face application. These sensors were dielectric permittivity sensor, gamma spectrometer, and EM induction sensor.

- Demonstrate benefit of integrated sensor deployment collecting a dense data set in a field environment.

- Demonstrate benefit of a robotic deployment system for automated data collection in a laboratory environment.

- Assess development needs for a dig-face system by soliciting input from DOE and private sector environmental remediation managers.

\section{Accomplishments}

Initial data were collected for three prototype sensors: a gamma spectrometer, dielectric permittivity sensor, and focused EM induction sensor. Data indicate that these sensors are feasible candidates for dig-face application; however, additional testing is recommended to define performance capabilities in realistic dig-face environments.

Testing was completed for automated deployment of dig-face sensors using a robotic gantry crane system. This pilot-scale testing used a soilbox to simulate the dig-face and identify control system issues and needs. The testing was hampered by numerous software and hardware problems showing the need for additional research. However, the utility benefit and feasibility of automated scan patterns were successfully demonstrated.

Field testing of a prototype dig-face characterization system was performed at a test trench at the INEL Cold Test Pit. The system's multiple sensors were deployed with a manual nonmetallic gantry designed and constructed to support obtaining dense data sets in a noninterfering environment. Data were obtained for several commercial sensors (magnetometer, EM sensor, chemical sensor) deployed over simulated targets in multiple passes as soil layers are progressively removed. Data indicate significant resolution improvement when operated in the dig-face mode of data collection. The data will be used to develop interpretation schemes to support the real-time interpretation of targets needed for dig-face application.

A workshop was held to solicit environmental restoration for development of the technology. Recommendations included development of technology in two directions: (1) large-scale system for support in retrieval of large buried waste pits and trenches, and (2) reduced system for support of remediation of small pits or piles of waste. Additional definition was supplied of recommended sensor development. 
A paper by N. E. Josten entitled "A New Application for Geophysics: Monitoring at the DigFace During Waste Site Excavation" was presented at the 1993 Symposium on the Application of Geophysics to Engineering, April 1993, San Diego.

Reports were issued, including Test Plan for Dig-Face Characterization Performance Testing, EGG-WTD-10766; Dig-Face Characterization Test Plan (Remote Testing), EGG-WTD-10771; Test Plan for Prototype Dielectric Permittivity Sensor, EGG-WTD-10812; Test Plan for Dig-Face Chemical and Radiation Assay System, EGG-WTD-10813; Prototype Ground Capacitance Sensor Final Report, EGG-WTD-11044; and Dig-Face Characterization Development Plan, EGG-WTD-11062 (see Appendix A).

\subsubsection{Electromagnetic Imaging as Applied to Mapping and Characterization of BWID-1D132018}

Funding for this TTP was received late in FY-93. Work on placing a contract for a subject matter expert began in FY-93, with actual work planned in FY-94.

The objective of this TTP is to demonstrate the use of three complementary state-of-the-art EM processing and imaging techniques in the delineation and characterization of buried waste sites. Three methods exist for generating an image of the subsurface from transient EM field data, and are in many respects complementary. One objective is to produce an image of the geoelectric structure of the INEL Cold Test Pit by applying these three imaging techniques to the high resolution multicomponent transient EM data that was acquired by Coleman/Blackhawk in May 1993. Another objective is to recommend an optimum set of acquisition parameters to support a system for TEM subsurface imaging of buried waste sites. This should be achieved by assessing both the acquisition methodology and imaging techniques applied over the Cold Test Pit. In the long term, the result will be to produce a reliable three-dimensional imaging method for buried waste detection, delineation, and characterization.

\section{Accomplishments}

The required surveys in Phase I were performed. The frequency domain electromagnetics (FDEM) were performed. The FDEM and time domain electromagnetics (TDEM) performed the best. The GPR system was not effective in the clay soil at the Cold Test Pit. Data fusion techniques were limited because of favorable results occurred only with the EM sensors. However, these results reinforce the importance of using multiple sensors in a site survey for characterization.

\section{Technology Transfer}

The research was conducted by the private sector (Coleman Research Corporation) through a Program Research Development Agreement. A paper is being prepared that will disclose the results of the research to the private sector at the Symposium on Application of Geophysics to Engineering and Environmental Problems in 1994. 


\subsubsection{Geophysical Workshop-1D132019}

Nonintrusive characterization techniques play an important role in remediation of buried waste sites within the DOE complex. BWID has taken an active role in the development and demonstration of characterization technologies for buried waste sites. To date, there are many technologies being developed and demonstrated for the Office of Technology Development by BWID. This workshop highlighted ongoing projects and obtained a better definition of the baseline technologies available for buried waste sites within the DOE complex.

The workshop focused on four objectives that are listed below:

1. To feature the current technologies being developed by the investigators funded by BWID during FY-93

2. To discuss emerging technologies that hold promise for buried waste characterization

3. To create a baseline for evaluation of nonintrusive characterization technologies

4. To create a set of data quality objectives to focus Office of Technology Development efforts in development of advanced technologies.

\section{Accomplishments}

A draft report entitled Proceedings of the Ground-Probing Radar Planning Workshop was issued September 23, 1993, by D. K. Parrish and W. M. Roggenthen of the South Dakota School of Mines and Technology.

\subsubsection{High-Speed Digital Radiography and Computed Tomography of Waste Drums-1D132020}

Funding for this TTP was received late in the fourth quarter of FY-93. Work was developed and initiated in FY-93; however, the majority of the work will not be completed until FY-94.

The work described in this TTP investigates the potential capabilities and applications of a commercial x-ray scanner for digital radiography (DR) and transmission computed tomography (CT) of waste packages, with emphasis on drums. A used, commercial DRCT scanner (circa 1987) has been acquired through government excess. The scanner uses $\mathrm{x}$-rays to measure density and nondestructively view the contents of waste drums. High throughput will be evaluated by investigating an area-type detector versus a linear array. A high energy $\mathrm{x}$-ray source could be installed for interrogation of high density drums and will be evaluated.

The objectives of this TTP are:

- X-ray scanning system optimized and demonstrated for drum assay. 
- A test and evaluation report describing the capabilities of the particular system under development at the INEL and potential applications for industrial $\mathrm{x}$-ray systems for highspeed DR and CT in waste characterization.

- A report describing how DR and CT data contribute to an integrated multiple measurement system for waste characterization.

\section{Accomplishments}

The x-ray scanner is presently being refurbished and will be on line at the INEL in FY-94.

\section{Technology Transfer}

Technology development and demonstration activities are being conducted with both government (INEL) and private sector (Scientific Measurement Systems, Inc.) involvement. Industry involvement in the development and demonstration phases will enhance commercial applicability of this scanner.

\subsubsection{Hazardous and Chemical Waste Separation at RWMC Excavation Sites-1D132021}

Funding for this TTP was received late in the fourth quarter of FY-93. Procurement of instruments was initiated in FY-93.

The work described in the TTP will be to develop a rapid chemical assay system (CAS) for hazardous chemicals in buried waste applications. The CAS is based on work performed for the last several years by the DOE Office of Arms Control. The CAS technology is currently in use by the Office of Arms Control and the U.S. Army for the characterization of various types of chemical weapons. The portable field use system can be carried by a single individual and used to assay a range of chemical weapons in the field. This technology will be adapted and modified for use with hazardous chemicals in DOE buried waste sites at the RWMC. The prompt gamma neutron activation analysis techniques uses a small CF-252 source.

Major tasks covered by this TTP are:

- Assess the effects of elemental interferences on the hazardous chemicals for which analysis is being performed.

- Train staff at the RWMC in the use of CAS and provide technical support as required.

- Perform an assessment of the potential applications to wastes at other laboratories in the DOE complex.

\section{Accomplishments}

In FY-93, system components were purchased. System adaptation, assembly, and testing will be conducted in FY-94. 


\section{Technology Transfer}

This task will assist in determining applications for this technology in the waste management/environmental restoration arena. The technology will also be implemented by INEL RWMC staff in 1994. Disclosure of this research through professional journals and presentations at technical conferences will enhance opportunities for transfer of this technology to private sector/industry for commercialization.

\subsubsection{EM Rapid Geophysical Surveyor-1D132024}

Funds for this TTP were received in the fourth quarter of FY-93. However, due to the recent availability of commercial systems, no additional development work was required in this area and funding was returned to DOE.

\subsubsection{USGS/DOE-ID Interagency Agreement-ID032002}

Funding for this work was received in the fourth quarter of FY-93. Deliverables will be completed in FY-94.

The objective of this project is to support an interagency agreement between the DOE-ID and USGS for the testing and data interpretation of an array of geological sensoring devices such as TDEM and TMGs. Reports documenting the data interpretation of these field tests will be provided in FY-94.

\subsubsection{BWID Remote Characterization System-1D332001, AL232006, OR132013, RL332016, and SF232001}

The main objective of this project was to demonstrate the feasibility of implementing a fully robotic, remotely-operated vehicle in an open-air environment for characterizing and locating simulated buried waste. The Remote Characterization System (RCS) consists of a remotelycontrolled, small low signature vehicle (LSV); a global positioning system (GPS) for tracking the vehicle; a high-level control station; and an array of geophysical, radiological, and chemical sensors that are mounted on the LSV. The LSV was developed as a platform for deploying a variety of sensors that may be interchanged for specific applications. Sensors that have been modified and mounted on the vehicle include (a) magnetometers (fluxgate and cesium-based), (b) a groundpenetrating radar (GPR) antenna, (c) an EM31 ground conductivity sensor, (d) a chemical detector, and (e) a gamma radiation detector.

The major goal in developing the LSV was to produce a vehicle that would be compatible with the operation of these sensitive geophysical instruments. The LSV and sensors were coupled with an ergonomically engineered control station to form the RCS. The RCS was designed and built as a cooperative effort by five national laboratories over the course of $11 / 2$ years. The design team used modular technologies and engineering approaches to build the RCS. These technologies were chosen in many cases to expedite the interlaboratory development. 
The features offered by the RCS provide several essential advantages over current manual characterization methods:

- It improves safety by removing workers from potentially hazardous waste sites (before and during removal of soil overburden)

- It decreases the time required for characterization by allowing for the simultaneous use of multiple sensors rather than one sensor at a time

- It reduces overall remediation costs by supporting rapid characterization of waste sites with multiple sensors

- It allows for denser data sets, giving a clearer resolution of data.

The test objectives consisted of both system test objectives and component test objectives. The RCS test plan identified the following system test objectives based on BWID demonstration requirements:

- Demonstrate the feasibility of remote site characterization

- Assess the response time and cost to characterize the pit and compare with the time and cost to manually survey an equivalent site

- $\quad$ Provide input into the Environmental Restoration CERCLA process for consideration for the Records of Decision and Safety Analysis for buried waste operable units

- Determine the accuracy and precision of the system in locating vertical waste pit boundaries

- Determine the accuracy and precision of the system in locating the basalt layer (belowgrade) in the vicinity of the pit boundaries

- Determine the accuracy and precision of the system in locating the depth of overburden/waste interface

- Assess the system's ability to detect and locate radioactive and hazardous chemical hotspots

- Monitor the effects of the environment on the RCS

- Assess the response time and cost to characterize the pit

- Assess the reliability of the system as observed during testing.

The RCS completed performance testing at the INEL Cold Test Pit. 


\section{Accomplishments}

In addition to testing the overall performance of the system, several individual components of the RCS were tested. These include the control system, sensors, camera system, data communications system, LSV, and positioning system.

The test results show the feasibility of remote site characterization using the LSV as a platform for deploying multiple sensors. The tests show that the performance of the magnetometers was greatly increased by operating on the LSV versus a vehicle made with ferrous metals. The effects of the vehicle on the EM31 could not be proven because the design changes in the configuration of the EM31 from long antennas to a short antenna resulted in an ineffective sensor. The effects were expected to be greatly reduced. The GPR, chemical sensor, and radiation detector appear to be relatively unaffected by operating on the RCS.

The accomplishments of the RCS are significant. Data were obtained simultaneously from three geophysical sensors, communicated back to the control station over a single communication link, displayed in real time, and archived for detailed postanalysis. The results from two types of magnetometers were excellent, and are the first such data remotely gathered without towing or pushing a trailer. The radiation sensor also provided very accurate and reliable data.

Another first for the RCS was the use of GPS data for accurate position stamping of the data. The use of the GPS eliminates sending personnel onto the survey site for time-consuming calibration and setup. The demonstrated accuracy of the GPS system is more than adequate and will be more accurate in the near future (specifically the real-time capabilities).

Emphasis of the RCS development was placed on the system-the platform, the communication system, the control station and van, and the data display-and were all designed to facilitate gathering of geophysical data in the field. These tests showed the successful integration of these subsystems, but also showed the need for further development of the individual components, especially the sensors and the communication system. The RCS as an initial prototype has been developed, but further improvements and numerous operating hours to ensure reliability are now needed.

Publications during the year included BWID Technology Preparedness and Status Report for the Remote Characterization System, EGG-WTD-10596; Remote Characterization System Test Plan, EGG-WTD-10704, and Remote Characterization System Technology Evaluation Report, EGG-2691 (see Appendix A).

\section{Technology Transfer}

Several DOE labs are involved or interested in furthering remote characterization. Its use with remote excavation and retrieval may enhance further funding and commercialization. The private sector, particularly those in the design or remote applications or hazardous remediation, should contact the developers for partnerships. The market for remote characterization is growing due to the high cost and safety aspects of intrusive characterization of waste sites and the growing number of sites that need this type of characterization such as areas with unexploded ordnance or unknown chemicals and chemical weapons. Therefore, the technology has application for Department of 
Defense and EPA Superfund sites. International markets also look promising with extensive cleanups in the newly independent countries and abandoned military testing areas.

\subsubsection{Active and Passive Computed Tomography Gamma Assay of Radioactive Waste-SF221209}

Work was initiated on this project in FY-92; however, full FY-93 funding was not received until the fourth quarter of FY-93. The majority of the work for this project will be completed in FY-94.

The objective of this TTP is to evaluate an active and passive computed tomography (A\&P CT) system on LLW and TRU waste contained in 55-gal drums. The A\&P CT uses a high purity germanium (HPGe) detector for nondestructive assay of gamma-emitting nuclides in sludge, combustibles, and metal matrices within a 55-gal drum. Assay is necessary for determining radiological content for below regulatory concern, $L L W$, and TRU waste disposition of stored wastes preassay and postassay of retrieved treated waste and residues; meeting shipping requirements; and meeting RCRA low-level mixed waste disposal regulations.

\section{Accomplishments}

The A\&P CT scanner has been developed to the state of system checkout and performance optimization.

\section{Technology Transfer}

Technology transfer is under way with the private partner, Bio-Imaging Research, through development of Waste Inspection Tomography (WIT) and the training, use, and data interpretation at DOE sites. The University of California San Francisco Medical School has medical expertise that is helping with this development while seeking advanced applications to medical diagnostics. Demonstration at numerous DOE sites will interest a variety of private environmental and waste assaying firms. Applications in the power industry and throughout the fuel cycle, particularly in fuel fabrication, are numerous. Safeguards monitoring and international use are also possibilities.

\subsection{Retrieval}

\subsubsection{Gas Contamination-AL021201}

FY-93 activities were a result of $\$ 73 \mathrm{~K}$ in carryover funds from FY -92 . No funding for FY-93 was provided. The main tasks included characterization and correlation of aerosol sources with specific BWID and decontamination and decommissioning activities, development of measurement techniques and instrumentation for source term characterization and monitoring; and evaluation and specification of monitoring equipment, evaluation of aerosol mitigation techniques, and development of operating procedures. 


\subsubsection{Retrieval Demonstration-ID121203}

A full-scale retrieval demonstration, sponsored by the DOE Office of Technology Development and coordinated by BWID, was held in June 1993 at the Caterpillar, Inc., (CAT) Edwards Training Center (ETC) near Peoria, Illinois. The purpose of the demonstration was to determine the feasibility of using standard man-in-the-cab operated equipment for the retrieval of buried TRU waste. Manually operated equipment and a highly skilled operator were chosen to define the best case for the use of construction type equipment in a waste retrieval scenario.

After a competitive bidding and review cycle, a subcontract was awarded to CAT to build a cold test pit filled with simulated buried waste and retrieve the contents using conventional type construction equipment. Martin Marietta teamed with CAT to provide the test plan, video and photographic documentation of the test, and final report. Martin Marietta engineers videotaped the retrieval demonstration from waste material preparation, through pit construction and waste retrieval, to site cleanup and waste haulage.

The primary objective of this demonstration was to evaluate the effectiveness of the full-scale equipment and end-effectors chosen for retrieving buried waste forms that are typical of buried TRU waste at the INEL and other DOE sites. Specific objectives include:

- Retrieve an average of $80 \mathrm{yd}^{3} /$ day of simulated buried waste, including materials from the stacked drums and boxes cell, earth berm, and randomly dumped drums and boxes and large objects cell. The $80 \mathrm{yd}^{3} /$ day goal has been established by Environmental Restoration as a target value for the retrieval and treatment rate of TRU buried waste. For additional information concerning the stated production goal, refer to the Buried Waste Integrated Demonstration Test Objectives (see Appendix A).

- Minimize the spread of dust during excavation by making slow, deliberate motions to lessen agitation of soil at the dig-face during excavation. Likewise, use care when transporting the load of waste from the dig-face to the funnel and transport box for dumping to minimize spillage.

- Determine if removal of buried waste from belowgrade or abovegrade is more productive.

- Determine the volume rate of retrieval for different waste orientations. Assess the average density of the waste/soil matrix.

- Determine the correct suite of end-effectors required to efficiently exhume the buried waste and soil.

- Determine how well the technology lends itself to remotization.

- Produce an rough order of magnitude cost to remotize the primary equipment used in the demonstration.

- Determine if the use of closed circuit television can enhance and improve operator views of the work area. 


\section{Accomplishments}

Excavation of the pit occurred in four passes, each $8 \mathrm{ft}$ wide and moving lengthwise along the pit. The first two passes were excavated from the belowgrade position and the last two from abovegrade. Various equipment combinations were tried at different times during the testing. The goal of the testing was to determine which piece of equipment worked most effectively from which position.

The 325L excavator with Balderson thumb and EL200 excavator with reversed bucket performed equally well retrieving waste from belowgrade. However, overall the $325 \mathrm{~L}$ with thumb proved to be the more versatile machine. The $325 \mathrm{~L}$ was consistently able to remove all varieties of simulated waste forms and large objects from belowgrade. The average volume of material removed by these excavators was just under $50 \mathrm{yd}^{3} / \mathrm{hr}$, or nearly $400 \mathrm{yd}^{3} /$ day (8-hour shift). This far exceeded the stated objective of $80 \mathrm{yd}^{3} /$ day.

Dust generation was minimal; however, the soil was fairly moist during most of the demonstration. Operation of the Balderson thumb was done in a careful and deliberate manner to ensure that regardless of soil conditions, the agitation of dust would be minimal.

Spillage of soil and debris by the $325 \mathrm{~L}$ was virtually nonexistent. For the purposes of the field demonstration, spillage was considered to be any material that dropped from the end-effector once the load had been picked up at the dig-face, swung to the funnel, and dumped into the transport box. Less than $1 \mathrm{yd}^{3}$ of material was spilled during the entire operation, and most of this was during the dumping operation from the thumb into the funnel and transport box. Any debris that was spilled was picked up by the thumb and bucket and placed in the transport box.

The 325L excavator with Balderson thumb demonstrated a high degree of dexterity. It was capable of picking over $1 \mathrm{yd}^{3}$ loads of heterogeneous waste with no spillage and then selectively plucking 1-in.-diameter cable from the debris and "folding" 50-ft lengths of the cable into segments short enough to be picked up and placed in the transport box. The thumb handled large objects well, including a storage tank, 6-ft metal cube, and machine tool. When necessary, combined use of the thumb and bucket provided delicate operation, such as picking up an intact drum and transporting it from the dig-face to the funnel without damage.

Operation of the $325 \mathrm{~L}$ from the abovegrade and belowgrade positions was not significantly different in terms of production when working in heterogeneous waste (not including large objects). However, the belowgrade position was preferred because operator visibility is enhanced, there is less risk of dig-face collapse, and the ease with which large objects can be removed. It was obvious from the field testing that work could be performed from either position.

Although the average production rate was determined to be nearly $400 \mathrm{yd}^{3} /$ day (8-hour day), it is recognized that this rate would be diminished by using a remotely operated system. As a rough first estimate (without the benefit of field testing), it is postulated that production would be cut by half. The $200 \mathrm{yd}^{3} /$ day projected for remote operation has a considerable margin over the original goal of $80 \mathrm{yd}^{3} /$ day. Planned follow-on work during FY-94 will involve a remote retrieval demonstration and will further define the expected production capability. 
Information gathered by Martin Marietta during the field demonstration on the use of twodimensional and three-dimensional camera systems will be helpful in the design of remote operated systems.

The technology to remotize the $325 \mathrm{~L}$ to work in a contaminated environment is currently available. A rough order of magnitude cost to remotize a $325 \mathrm{~L}$ is $\$ 1,000 \mathrm{~K}$. This price is only for the remote control system and does not include machine price, hardening of the excavator for operation in a contaminated environment, or other related costs.

The demonstration was performed in a safe and environmentally responsible manner with no injuries, damaged equipment, or threat to the environment.

At the conclusion of the excavation, the simulated debris was loaded and hauled to an approved landfill for permanent disposal. The cold test pit was reclaimed with clean fill material, compacted, and graded to the original contours of the surrounding area.

It has been shown that the retrieval of buried waste can be accomplished with standard type equipment. This equipment will ultimately require modification to work in a contaminated environment, but the technology to accomplish this is available now. Through an aggressive testing and demonstration program, a family of remotely operated equipment can be developed during the next several years that will be suitable for the retrieval of buried waste.

Reports issued during the year included Test Plan for Retrieval Demonstration, EGG-WTD-10744, and Full-Scale Retrieval of Simulated Buried Transuranic Waste, EGG-WTD-10895 (see Appendix A).

\section{Technology Transfer}

This class of technology is already in the commercial sector. The remotization of this equipment offers opportunities for collaborative efforts, which are planned by BWID in FY-94. The results will be presented in technical journals and at conferences.

\subsubsection{Retrieval Related Technologies-1D132007}

There were several technologies that were investigated under this TTP. These included overburden removal and sheet pile retaining walls. Each of these is discussed below:

\section{Overburden Removal}

The development, demonstration, testing, and evaluation of the system for overburden soil removal and skimming was jointly funded by the DOE Office of Technology Development through both BWID and the Uranium in Soils Integrated Demonstration Program. The concept and design of the overburden removal system was developed for BWID by Sonsub, Inc., under subcontract to EG\&G Idaho, Inc. Removal of overburden soils from subsurface disposal areas was demonstrated, tested, and evaluated in July 1993 at the INEL using state-of-the-art engineered excavation equipment. 
The overall objective of this demonstration was to explore the effectiveness of equipment to remove overburden soil in precise controllable increments. The overburden soil is expected to be clean; however, local hotspots may be present in the actual buried waste pits. Therefore, another crucial technical aspect of the overburden removal included minimizing dust generation and the potential associated spread of airborne contaminants. It is anticipated that removal procedures will require both presampling of the excavation region and some screening for hotspots during operations to preclude categorization of contaminated soil as clean soil.

Specific objectives and summary results are as follows:

Objective: Demonstrate that increments of soil can be removed in predetermined and controlled thicknesses and determine the precision and accuracy of the removal equipment and processes. The demonstration used a standard modern hydraulic excavator with a specially adapted end-effector to skim 3-, 4-, and 6-in.-thick layers in 3-ft-wide strips from the INEL Cold Test Pit.

Results: The overburden soil removal equipment demonstrated its capability to remove soil from buried waste pits with extreme precision and accuracy. The precision for all the test runs was within the $\pm 1.0 \mathrm{in}$. performance specification for the equipment with the average precision being \pm 0.57 in. The average accuracy (deviation from the depth of cut expected) was only -0.08 inches, or 0.08 in. below the target depth.

Statistical analysis of the test data showed that the average depth of cut did not exceed 1 in. below the target depth.

Objective: Demonstrate the ability of the equipment and processes to control the generation of fugitive dust during removal of the soil and determine if dust was generated at the point of excavation at levels above background.

Results: The overburden soil tests successfully gathered data sufficient to determine the amount of fugitive dust generated during removal operations. The dust collected downwind of the excavation area averaged approximately 4.5 times greater than that of the background dust measured upstream of the excavation area during the test. Visual evidence (eye witness and videotaped) shows that the dust collection system on the end-effector was effective in scavenging much of the visible dust generated during the soil removal operations.

Statistical analysis of the test data showed that the average of all dust samples collected for each test were less than 10 times the test background levels.

Objective: Demonstrate the ability of the soil removal equipment and techniques to control the spread of contamination. By quantifying contamination spread using the collection and measurement of samples, determine if erbium was detected at levels above background during overburden soil removal operations.

Results: The overburden soil removal tests demonstrated the ability of the equipment and processes to control the amount of contamination spread during soil removal. Erbium (the rare 
earth tracer utilized) was detected downwind of the excavation area at levels averaging greater than the test background level (measured upstream during the test).

Statistical analysis of the test data showed that the average of all tracer samples collected for each test were greater than 10 times the test background levels. However, the pretest background tracer measurements were often in the insignificant or nondetectable range, allowing little conclusive comparison with the test background tracer data.

Objective: Demonstrate and measure the maneuverability of the removal equipment to work in or around the Cold Test Pit and excavate around simulated or real obstacles within the overburden removal area.

Results: The overburden soil removal equipment demonstrated that the required envelope is $55 \mathrm{ft}$ wide on the sides of the pit, $50 \mathrm{ft}$ wide on the ends of the pit, with a clearance of $34 \mathrm{ft}$ above grade level. The excavator was able to maneuver easily around obstacles, requiring no additional envelope clearance than during normal excavation. A 2:1 slope on the sides of the pit was maintained during maneuvering of the end-effector. The end-effector was also able to remove soil in the corners of the pit. The required size of a containment structure to perform this demonstration would be $150 \mathrm{ft}$ wide, $230 \mathrm{ft}$ long, and $34 \mathrm{ft} \mathrm{high}$. This assumes the excavator would not be driven on the pit, and that operations would be similar to those demonstrated in the test.

Objective: Demonstrate that overburden soil can be removed at rates that would be representative of a production retrieval operation using the equipment, processes, and procedures described in this test plan.

Results: Removal of the overburden soil demonstrated that production retrieval rates are achievable. The average removal rate of all three phases was $12.29 \mathrm{yd}^{3} / \mathrm{hr}$. A typical buried waste pit of 1 acre $\left(43,560 \mathrm{ft}^{2}\right)$ with a 4-ft-thick overburden would contain approximately $6,453 \mathrm{yd}^{3}$ of overburden soil. At the average rate of $12.29 \mathrm{yd}^{3} / \mathrm{hr}$ as reported here, it would take 525 hours for a single machine to remove this overburden. Based on the Phase III data, an optimized bucket and an experienced operator should be able to easily achieve a rate of at least $20 \mathrm{yd}^{3} / \mathrm{hr}$. This would decrease the time for removal of the 1 acre overburden to 322 hours. Of course, additional machines would decrease this further.

A very significant occurrence during this demonstration was the unexpected exposure of a $2 \times 4 \mathrm{ft}$ hole extending down into a wooden waste box. This occurred at an elevation suspected to be $2-4 \mathrm{ft}$ above the buried waste. Apparently, the top of a waste (simulated) box had collapsed allowing the soil above it to fall into the box creating an underground chamber.

If this had been a pit with contaminated waste, the area and the equipment would have been unexpectedly contaminated. This supports the fact that heavy equipment, even with low ground pressure, cannot operate over the top of the pit once overburden removal has begun due to the danger of falling through into contaminated waste. Even though heavy equipment is regularly moved across these pits, it is impossible to predict at what level they might break into a contaminated area during overburden removal. 
It also supports the contention that if overburden is being removed from a pit or trench that contains waste which could generate airborne contaminants, a containment structure should be in place. It is obvious from the occurrence noted above during this demonstration that it is impossible to predict, with any level of certainty, at what depth a path for airborne release might be opened into the waste.

The data obtained in this demonstration will eventually be used by Environmental Restoration during the feasibility study for parts of the RWMC and possibly by additional efforts in other locations. The data will also be used by Environmental Restoration to project additional technology needs for BWID out year planning.

Published reports included the Test Plan for the Overburden Removal Demonstration, EGG-WTD-10716, and Removal of Overburden Soils from Buried Waste Sites, EGG-WTD-10767 (see Appendix A).

\section{Technology Transfer}

Through collaboration with the private-sector partner, SONSUB, this technology is now available in the commercial sector. Publication of these results in technical journals and presentations at conferences will increase the interest of end users for additional applications.

\section{Sheet Pile Retaining Walls}

An analytical study of ground retaining (waste isolation) systems for use during retrieval of buried waste at the RWMC at the INEL or other subsurface disposal areas at the INEL, ORNL, or the DOE Hanford Site was conducted. The study resulted in a report entitled Evaluation of Steel Sheet Pilings to Create Vertical Retaining Walls During Buried Waste Retrieval, EGG-WTD-10780, that discusses the technical aspects of using sheet pile retaining walls for possible future use during waste retrieval operations (see Appendix A). Vertical retaining walls can help reduce excavation and minimize containment structure size. Placement of ground retaining systems limits disturbance to the immediate site. Excavation is performed in a clearly defined space of clean lines and places the retrieval operation in a stable surrounding. Additionally, it is conceivable that the system would serve as a foundation for a confinement structure located over the area being retrieved.

The installation of a vertical retaining wall will eliminate the need for handling material that would have been excavated using a 2:1 slope, thereby saving substantial earthwork, limiting the amount of exposed area, preventing sloughing, minimizing the span of a confinement structure, providing a foundation for the confinement structure, and restricting the excavation to the pit or trench of interest. The vertical retaining wall concept will not interfere with excavation equipment and will actually enhance the ability of equipment to retrieve the buried waste because a "backing" surface will be provided. It will be easier to dig and excavate soil and debris next to the retaining wall rather than a dirt slope. The retaining wall can also interface with the containment structure. This is a simple interface as confinement structures are light compared to a standard building. Loads imposed on the sheet piling will be compression forces and lateral loading from wind transmitted from the structure. Both of these conditions can be easily accommodated for in the design. 
Earth retaining systems may include methods such as sheet piling, H-piling, concrete retaining walls, ground freezing, grouting, or other innovative technologies. Proposed methods may rely on embedded or anchored systems, mass, or a combination of technologies.

\subsubsection{Contamination Control-1D121210}

This TTP consists of several independent technologies. Each technology will be addressed separately.

\section{Contamination Control Unit}

The Contamination Control Unit (CCU) was developed by BWID for the DOE Office of Technology Development. The CCU is a self-contained, field deployable trailer-mounted system designed to control contamination spread at the site of TRU handling operations. The systems contained in the unit are capable of performing multiple contamination control functions in dusty conditions where contamination spread is linked with dust spread. Examples of the system's capabilities are buried TRU and LLW retrieval and treatment and emergency response for hazardous and radioactive materials.

The $\mathrm{CCU}$ is capable of dispensing soil fixatives, dust suppression agents, and misted water, and uses a vacuum system. The Dry Fog Ultrasonic Misting System uses a specially designed nozzle to mix air and water to create a fine cone of mist. The misting heads are placed in strategic positions without interfering with other local activities to provide contamination control for digging and dumping operations. In the demonstration, the Dry Fog Ultrasonic Misting System was used to control aerosolized soil and provided adequate dust control. Misting in wind-controlled conditions proved to be effective. The soil fixative application system uses a soil fixative (3M Foam) mixed with water to create a pale yellow foam material that is dispensed using volume expansion nozzles. This product provides a long-term, vapor-suppressing foam for covering uneven contaminated soil (e.g., steep sloping dig-faces).

The systems in the CCU are ready for full-scale testing or application. All systems have been tested thoroughly and evaluated qualitatively. The CCU has already been deployed for contaminated soil excavation operations from the Westinghouse Hanford 116-F-4 waste site (a $100 \mathrm{~F}$ Area pluto crib) to control TRU and low-level soil contamination and to support the testing of different types of dust control products.

\section{Accomplishments}

The CCU performed as expected, but especially well during a simulated TRU buried waste retrieval demonstration. The CCU did not have any down time, and all systems worked properly. Personnel operating the CCU became experienced and proficient by the end of the demonstrations.

The CCU is also ready to provide for emergency response. There are products immediately available to provide contamination control using soil fixation (3M Foam) and dust suppression (Flambinder), if needed. The CCU can be moved throughout the DOE complex for immediate use (e.g., Fernald, Savannah River, and Hanford). 
All dust control products were individually tested in glovebox and engineering-scale experiments. The field tests were qualitative to show the fieldability of the apparatus and deployability of the dust control products. Observations of the apparatus and dust control products are provided below.

The 3M Foam is an adequate fixative that shows field deployable attributes, but it has cost constraints. The key to optimum performance of $3 \mathrm{M}$ Foam is using the product in the proper situation and under the right conditions. Applying the $3 \mathrm{M}$ Foam product as a soil fixative between digging operations of a simulated TRU buried waste retrieval effort (in Cell 4 of the Remote Excavation System demonstration) proved to be inappropriate for a real work application. The best application for this product is covering dry, contaminated soil or covering items with loose contamination that are expected to be left undisturbed inside of a containment structure (e.g., Pit 9 reclamation).

The dust suppression application system is the simplest, yet the most versatile system contained on the CCU because any type of dust suppressant, surfactant, or fixative (also known as a crusting agent) that solubilizes readily with water can be used with this system.

Of all the products tested by the CCU, Flambinder (calcium lignosulfonate) was the best overall. XDCA (a sugar beet polysaccharide) is also adequate, and both are more durable than WenDon (an encapsulant). Flambinder was best suited for contamination control in traffic areas, in the excavation area, and on the dumping area. The XDCA was best suited for contamination control on smooth, light traffic areas. The potato starch product was best for short-term, steep dig-face fixation of dust and loose contamination.

The potato starch mixture formed a protective crust that was not readily resolubilized. The crust maintained its integrity for at least 1 week before ultraviolet rays began to degrade its quality. The starch adhered to vertical soil slopes extremely well when applied slowly.

The vacuum system in the CCU is a nuclear grade, high efficiency particulate air (HEPA) filtered system. The vacuum system is capable of removing loose particulate debris including small particles in the micron range up to large debris $1.5 \mathrm{in}$. in diameter. The vacuum system provides a means to rapidly decontaminate equipment, personnel, and work areas.

Although the vacuum system performed as expected, it needs further evaluation using sieved soil spiked with rare earth tracer. A test like this would demonstrate the contamination control of the vacuum system and identify possible contamination problems that could occur within the system or trailer.

Overall, in the field, the $\mathrm{CCU}$ achieved dust control efficiencies equivalent to those obtained during laboratory testing. A dust control efficiency of $70 \%$ was obtained by dust loadings on filters for excavation cases with and without contamination control.

Published reports included Test Plan for the Field Evaluation and Demonstration of the Contamination Control Unit, EGG-WTD-10717; Contamination Control Unit Operations Manual, EGG-WTD-10886; and Evaluation of the Contamination Control Unit During Simulated Transuranic Waste Retrieval, EGG-WTD-10973 (see Appendix A). 


\section{Technology Transfer}

The system is being used throughout the DOE complex. Disclosure of this research through professional journals and presentations at technical conferences will ensure transfer of this technology to private sector contractors that may be performing waste site remediations.

\section{Electrostatic Curtain}

An engineering-scale electrostatic enclosure demonstration was performed at the INEL's Test Reactor Area (TRA). This demonstration was sponsored by BWID for the DOE Office of Technology Development. Electrostatic curtain technology may be applied as a contamination control technique during handling of TRU material such as retrieval of buried waste. The experiments in this demonstration included in an inner and outer enclosure with a ventilation system and was designed to demonstrate the applicability to full-scale operations. The electrostatic curtain is part of an overall in-depth strategy for contamination control during TRU waste recovery operations.

\section{Accomplishments}

The engineering-scale experiments were performed inside a double enclosure with a ventilation system. These test represent a considerable size enhancement over previous glovebox tests that confined the experiment to a 4 in. ${ }^{3}$ test section within the glovebox. The outer enclosure consists of a $12 \times 8 \mathrm{ft}$ stainless steel Perma-con structure with two personnel doors. The inner enclosure was a Nuclear Power Operators tent $4 \times 6 \times 6-1 / 2 \mathrm{ft}$. The inner enclosure contained the dust generator and test materials on the test rack. The ventilation system and HEPA filter interface and test section passed through the back side of the Perma-con enclosure connecting to the output opening of the inner enclosure.

The test section in the ventilation system interface was used for testing the various electrostatic devices for removing plutonium from the aerosol. The electrostatic curtain devices consist of $3 \mathrm{M}$ electric filter material, a test fixture that used the electric field from a CRT, and a parallel arrangement of metal plates referred to as a separator.

The materials tested in the inner enclosure were polyethylene, anti-static building fabric material, and stainless steel. The materials had coupons (made of the same material) attached for gravimetric and radiochemical analysis.

Photographs taken with a scanning electron microscope (SEM) operated in the compositional mode identified particles containing high $\mathrm{Z}$ elements. The high $\mathrm{Z}$ element could then be identified as plutonium by using the SEM dot mapping capability. The SEM also provided size distribution printouts for selected samples to help characterize the aerosol for contamination control. The SEM analysis and photographs showed that the plutonium was attached to and compounded with the soil particles. This explains why all the plutonium could not be separated from the dust particles. The electrostatic separation process requires that the plutonium particles be self-charging and develop a net positive charge.

The Inhalation Toxicology Research Institute at Albuquerque, New Mexico, prepared the soil mixture for the engineering-scale tests. The ${ }^{239} \mathrm{Pu}$-labeled soil was checked for activity level and size 
distribution to characterize the soil for the demonstration tests. The activity levels varied from 16.2-590 pCi/g with an arithmetic average of $187.1 \mathrm{pCi} / \mathrm{g}$. This distribution was considered nonhomogeneous compared to the planned values. The average particle diameter ranged from 8.89-13.77 $\mu \mathrm{m}$ as determined by SEM analysis with the largest particle $220.6 \mu \mathrm{m}$ in diameter. The cascade impactor data indicated that $47 \%$ of the mass was greater than $10 \mu \mathrm{m}$ in diameter and less than $1 \%$ was smaller than $1.1 \mu \mathrm{m}$.

The nonhomogeneity (16-590 $\mathrm{pCi} / \mathrm{g}$ for source dust samples) was also observed in previous glovebox tests using the plutonium contaminated Rocky Flats/INEL soil blend. Thus, it is probably what might be expected in a waste recovery operation involving TRU waste.

The percent of $\mathrm{PuO}_{2}$ removed in the engineering-scale tests was lower than for the glovebox tests. This indicates that longer distances and higher elevation of the separator in the engineeringscale test resulted in heavier $\mathrm{PuO}_{2}$ particles falling out before reaching the test section. In addition, many of the smaller particles attached to dust particles passed through the electrostatic field on neutralized dust particles. Only those particles that contained enough plutonium to be self-charging could be separated. The amount of plutonium that could be removed by the parallel plate separator used in these experiments ranged from $20.5-51.1 \%$.

The inner and outer enclosures worked adequately for plutonium handling operations. The Perma-con enclosure with its clip-together construction method was easy to assemble and can be moved or extended with additional panels. The configuration can be changed when reassembling because the panels are interchangeable. The inner enclosure was a light-weight, see-through PVC with an aluminum tubing frame that could also be moved easily. This kind of inner enclosure could be adapted to a larger configuration such as might be used in a full-scale waste recovery operation.

Evaluation of the electrostatic materials controlling plutonium confirmed what was learned in prior glovebox tests. A conducting material that is grounded is the best choice to minimize electrostatic charge buildup on the walls and collect minimum amounts of dust and plutonium. The conducting material will also minimize the spread of contamination because electrostatic buildup is eliminated. A grounded, anti-static, construction fabric was second best in that is also eliminates charge buildup. However, the longer discharge time for static charges allows more time for the particles to stick to the surface than for conducting materials. Insulating material sheets like polyethylene will collect various amounts of static charge that can have either a positive or negative sign. Thus, the test results on polyethylene were unpredictable.

Evaluation of the electret filter as an electrostatic device in the ventilation system also confirmed previous glovebox test results. Electrets filter out respirable size dust particles very well and have a lower air resistance than pure mechanical filters. The mass removal efficiency was within the manufacturer's specification of $97.5-99 \%$ for the air velocities used in the tests.

The electrostatic field from the CRT was too low $(65.8 \mathrm{~V} / \mathrm{cm})$ to make it a good electrostatic source for this application. The capability to attract plutonium using the CRT would be the same as that for parallel plates but with a lower voltage of only $65.8 \mathrm{~V}$ on the stainless steel plates.

A $98 \%$ plutonium removal efficiency was considered a successful application according to the test plan. Since the plutonium is so well attached to an compounded with the dust particles, 
removing $98 \%$ or more of the plutonium with electrostatic devices would require a higher voltage electrostatic precipitator. The other options are to use electret filters or a virtual impactor. All of these devices would remove both dust and plutonium from the air flowing in the ventilation system. However, the virtual impactor could be tuned to remove only those particles above a given diameter.

\section{Technology Transfer}

Full-scale demonstration of this technology has not been completed. An opportunity exists for private-sector industry interested in further development and commercialization of the electrostatic curtain. Full-scale demonstration may be conducted at the INEL in 1995.

\section{Rapid Transuranic Monitoring Laboratory}

There was a field test of the Rapid Transuranic Monitoring Laboratory (RTML) conducted at the INEL during the summer of 1993 . The RTML is a mobile laboratory developed at the INEL for use in characterizing low-level radiological source terms at buried radioactive waste remediation sites. Analytical instruments installed in the RTML include a thin window, germanium photon spectrometer equipped with an automatic sample changer, two large-area ionization chamber alpha spectrometers, and four alpha continuous air monitors (CAMs). The RTML was tested for the BWID program, TRA, and the Cold Test Pit.

Direct alpha spectrometry with a large-area ionization chamber and photon spectrometry with a high-resolution, n-type, extended range germanium spectrometer were shown to be rapid, sensitive methods for the measurement of TRU isotopes on smears and in soil and dust samples. The two analysis techniques do not require elaborate sample preparation or time-consuming chemical separations; soil samples for the photon spectrometer are dried and sieved before analysis, and soil samples for the ionization chambers are dried, sieved, and ground in $30 \%$ ethanol before analysis. Smears and filters are analyzed directly without any sample preparation.

The RTML consists of two separate trailers that are powered from portable diesel generators. One trailer, $8 \times 24 \mathrm{ft}$, houses the sample preparation laboratory that is equipped with a Class A fume hood, a drying oven, sieving equipment, two analytical balances, and sample containers. Samples are received and prepared for analysis in this trailer. The second trailer, $8 \times 48 \mathrm{ft}$, houses the germanium photon spectrometer, two ionization chamber alpha spectrometers, and a computer that controls operation and analyzes the spectral data acquired by the spectrometers. The computer is a VAX 4000 model 100 equipped with terminals and printers to display and generate the analysis results reports. The RTML is also equipped with four alpha CAMs that are operated remotely from the RTML analysis trailer. The alpha CAMs can be operated at distances up to $200 \mathrm{~m}$ from the trailer.

\section{Accomplishments}

Including quality control and blind soil standards, over 300 samples were analyzed by photon spectrometry, and 136 samples were analyzed by ionization chamber alpha spectrometry during the field test. Seventy-nine samples were analyzed during a 24-hour period with the photon spectrometer. In a 5-hour time period of continuous work, 33 prepared samples were analyzed with the two ionization chamber alpha spectrometers for an average rate of about 6 samples per hour. If we assume that this rate can be maintained for 7 hours during an 8-hour shift, the total number of 
samples that can be analyzed with the ionization chambers during an 8-hour shift is 42 . Based on these sample throughput rates, which together equate to 121 samples being prepared and analyzed in 1 day, the cost to analyze one sample is about $\$ 18$.

All spectral analyses of the photon data were performed automatically with no input from the operator beyond basic sample parameters. No positive results were obtained for either the 143 soil samples analyzed by photon spectrometry, or for the 96 soil samples analyzed by ionization chamber alpha spectrometry. Each of the 96 analyses of the 20 blind soil standards performed by photon spectrometry identified and quantified one or more of the four radionuclides present in the standards. There was some underestimated bias that occurred and potential systematic errors are being actively pursued to remove this bias and reduce the total uncertainty.

Published reports included Test Plan for Demonstration of Rapid Transuranic Monitoring Laboratory, EGG-WTD-10758; Operating Procedures for Rapid Transuranic Monitoring Laboratory, EGG-WTD-10898; and Field Test of the Rapid Transuranic Monitoring Laboratory, EGG-WTD-10935.

\section{Technology Transfer}

The system is comprised of commercially available components. A commercial partner could begin manufacturing the integrated system. Disclosure of this research through professional journals and presentations at technical conferences will enhance transfer of this technology to private-sector contractors that may be performing waste site remediations. The INEL Environmental Restoration Program is planning to use the system as a screening tool during Site-wide soil sampling in 1995.

\subsubsection{Three-Dimensional Dynamic Graphic Simulation-1D132022}

Funds for this TTP were received late in the fourth quarter of FY-93. The contract was initiated, but work and key deliverables will not be produced until FY-94.

The objective of this TTP is to modify existing commercially available software packages to provide a graphical Three Dimensional Dynamic Simulation Tool (3DDST) for BWID systems analysis. The 3DDST will illustrate the BWID characterization/retrieval/ex situ treatment configuration option and visually define the relative merits of proposed technical development activities.

Major tasks include:

- Demonstrate the capabilities of 3DDST

- Modify and conduct final demonstration.

\section{Technology Transfer}

Commercial participants for software and hardware will be identified and obtained in the first phase of this effort. It is envisioned that the demonstrated prototype system will foster the optimization of this approach. This action will ensure the availability of this system to the ER/WM elements at all applicable DOE sites as well as other complex hazardous waste sites. 


\subsubsection{Multi-Axis Crane-1D332002}

This project involves the integration of a sophisticated control system with a multi-axis crane system at the INEL. In FY-93 the crane was erected and hardware installation was initiated. In FY-94 the crane will be tested. The crane has four bridges, four trolleys, a supporting structure, a cadre' of hydraulically powered tools, closed circuit television cameras, two control consoles and associated supporting equipment. The system consists of twenty-six axes of motion. The control system will demonstrate that control of all of these axes of motion is feasible and that this addition will assist operations personnel by providing supervisory control of the entire system during operations. The project will also demonstrate the ease of integrating a sophisticated supervisory control system with commercially available hardware.

Many concepts exist for accessing buried wastes. Use of an overhead crane provides a positive means of universal access to these materials. The multi-axis crane system provides the capability of remotely performing considerable amounts of work. The ability that this system offers (i.e. simultaneous deployment of more than one type of remediation technology at a time) provides great value to this system. Ease and efficiency of operation will be considerably enhanced by the addition of a control system. The enhancements provided by the control system will provide meaningful supervisory control to this complex system, where the smallest judgement error may result in damaged equipment, unnecessary contamination spread, or lost time.

The objective of the demonstration will be to demonstrate the feasibility of a remote control system. The supporting objectives are:

- Determine the precision and accuracy of the system

- Determine the reliability of the system

- Determine the useability of the system

- Determine the factors that may affect system performance

- Develop a knowledge base on remote control systems such that the system can be improved.

\section{Accomplishments}

An internal report was issued November 1992 entitled Buried Waste Integrated Demonstration-Technology Status Report for the Multi-Axis Crane (WTD-92-051), written by K. M. Croft (see Appendix A).

A "Protech" technology profile was completed and submitted June 1993.

A final letter report (BEG-04-94) was issued to DOE-ID on January 24, 1994 (see Appendix A). 


\subsubsection{Remote Excavation System-1D332004, AL232007, RL332017, OR132014, and SF232002}

The main objective of this project was to demonstrate the feasibility of implementing a remotely operated excavator for skimming layers of soil in an open-air environment and for retrieving simulated waste in an enclosed area.

The Remote Excavation System (RES) test objectives included both system and component test objectives. The system test objectives included:

- Demonstrate the feasibility of remote excavation of buried waste, including waste containers and large buried objects.

- Evaluate the system's ability to skim layers of soil.

- Compare remote and manual performance of the backhoe in retrieving buried waste.

- $\quad$ Provide input into the Environmental Restoration CERCLA process for consideration for the Records of Decision and Safety Analysis for buried waste operable units.

- Measure the spread of nonhazardous tracers that occur during open-air soil skimming operations at the Cold Test Pit. Develop further understanding of the expected spread of contamination from actual retrieval operations at an INEL TRU waste pit.

- Monitor and record the environmental effects of the RWMC on the system.

- Determine waste retrieval and overburden removal rates using the RES at the Cold Test Pit.

- Demonstrate the ability of the vehicle to transfer waste to $4 \times 4 \times 8$ boxes.

- Record and evaluate any system failures.

In addition to these system test objectives, the following components were tested: human factors/control system, camera system, data communications system, and the small emplacement excavator (the vehicle itself).

\section{Accomplishments}

Results from the INEL testing show the system to be reliable and easy to use. While the small excavator provided for development of the RES is not appropriate for many waste site remediation operations, the subsystems developed for the RES are ready for transfer to a larger excavator. The RES is also ready for implementation in smaller-scale operations, for example, hotspot retrieval.

Comparisons between manual backhoe operation and remote operation revealed only minor differences in waste and soil retrieval rates. Because of the current status of camera technologies and the lack of depth perception provided by conventional cameras, their precision and accuracy of 
removing layers of soil was less using the RES than using a manually operated backhoe. Comparing the costs of manual and remote operation, the cost of remote operation (based on 6 hours of productive operating time) is estimated to be only one quarter of the cost of manual operation, resulting in an enormous decrease in the overall cost of waste site remediation. Since a major portion of the cost savings is a result of an increase in the number of productive hours per day, the time required to remediate a particular site is also drastically reduced.

Published reports included the Technology Preparedness and Status Report for the Remote Excavation System, EGG-WTD-10599; Remote Excavation System Test Plan, EGG-WTD-10703; and Remote Excavation System Technology Evaluation Report, EGG-2710.

\section{Technology Transfer}

Through these tests, the RES is shown not only to be a safer method of waste site remediation, but also a faster and less expensive method. Disclosure of this research through professional journals and presentations at technical conferences will ensure transfer of this technology to private-sector contractors that may be performing waste site remediations. Many companies have expressed interest in the control technology and the operator interface technology developed by ORNL, and several are pursuing CRADA scope negotiations. Mechanisms will be sought to transfer the technology to interested parties.

\subsubsection{Fixation of Soil Surface Contamination Using Natural Polysaccharides-RL432002}

The objective of this TTP was to demonstrate the use of inexpensive, environmentally acceptable, dust suppression materials that will not adversely impact subsequent soil treatment processes.

Natural polysaccharides were evaluated as alternatives to commercially available dust-control agents for application in buried waste and contaminated soil remediation situations. Materials were identified and evaluated with specific criteria in mind:

- The materials must be environmentally benign and must not introduce any additional hazardous materials

- They must be effective for at least 2 or 3 days, but they do not necessarily have to be effective for more than 2 to 3 weeks

- They should be relatively resistant to light traffic

- They must not interfere with subsequent soil treatment techniques, especially soil washing

- They must be relatively inexpensive.

\section{Accomplishments}

Two products, a pregelled potato starch and a mixture of carbohydrates derived from sugar beets, were selected for evaluation. Testing included small- and large-scale field demonstrations, 
laboratory physical property analyses, and wind-tunnel evaluations. Field demonstrations were conducted to evaluate the effectiveness of the products in a remediation-type setting and to identify specific situations in which the products were most useful. Laboratory analyses were performed to evaluate the ease with which the products could be removed from various types of soil, indicating the relative effect that the products might have on a soil washing system. Wind-tunnel evaluations allowed for quantitative evaluations of the degree of wind erosion protection provided by the products.

The laboratory analyses indicated that both the potato starch and the sugar beet products were readily removed from sandy soil. The starch also was easily removed from a silty soil from the INEL. The sugar beet solution was more difficult to remove from the silty INEL soil, indicating that it might induce a slight reduction in soil-washing efficiently of this soil type. The potato starch probably would have no effect on a soil-washing system. Neither product was easy to remove from a Hanford site fine silt soil.

Wind-tunnel evaluations indicated the potato starch was most useful for steep, dig-face stabilization and was preferable in this application to a dust suppressant foam, which also was tested for that purpose. The sugar beet product was most useful for general dust control around an excavation site, especially when subsequent soil treatments are planned. If general, long-term dust control is required and subsequent soil treatment is not planned, calcium lignosulfonate is preferable. This preference is based on both cost and performance.

Each of the products were shown to have a strong potential for use as dust-control agents and soil fixatives in excavation and remediation environments. Each had particular situation-specific advantages and had different end uses.

A report entitled Fixation of Soil Surface Contamination Using Natural Polysaccharides," WHC-EP-0688, was issued in September 1993 by M. R. Sackschewsky (see Appendix A).

\section{Technology Transfer}

The markets for commercial products have been established and all but one product are commercially available. Proof of successful application on specific DOE soils during typical retrieval operations will enhance viability of polysaccharide products as well as biodegradation and short-term low residue requirements.

\subsection{Treatment}

\subsubsection{Pad A Treatability Studies-1D121205}

The activities covered in this TTP were a result of FY-92 carryover funding in the amount of $\$ 83 \mathrm{~K}$.

The objective of this effort was to determine if the vitrification co-processing of radionuclidecontaminated nitrate salts and soils is an effective remediation method for destroying the salts while stabilizing the soils. 
Laboratory-scale melting of radionuclide-contaminated INEL Pad A nitrate salts and Acid Pit soils was conducted using crucibles in a bench top furnace together at $1550^{\circ} \mathrm{C}$ simulating ex situ vitrification treatment. The new waste form ranged from a high sodium to more durable borosilicate glass, depending on the ratio of Pad A salts and Acid Pit soils mixed. Glass oxidation reduction and handling properties are controlled by using additives such as boric acid and carbon. The salt/soil/additive ratios determine the range of glass compositions; maximize mass and volume reduction, durability, and immobilization of hazardous and radioactive metals; and minimize viscosity and offgas generation for wastes prevalent at the INEL and other DOE sites.

\section{Accomplishments}

- $\quad$ Presented poster at 3rd Technology Information Exchange in Pleasanton, California

- $\quad$ Presented a poster and paper at Waste Management '93 in Tucson, Arizona

- Completed lab test analysis and issued an informal report entitled Laboratory-Scale Vitrification of Low-Level Radioactive Nitrate Salts and Soils from the Idaho National Engineering Laboratory, EGG-WTD-10640, July 1993 (see Appendix A).

\section{Technology Transfer}

The collaboration between DOE/INEL Environmental Restoration and industrial contractors General Atomics and EnVitco provided technology transfer from the inception. The input of a major melter manufacturer and major nuclear treatment company helps to disseminate technology throughout the DOE complex and in other waste processing sites. The use of the technology both from a process ability and waste minimization standpoint make it particularly valuable for commercial marketing.

\subsubsection{Ice Electrodes-1D121211}

The activities from this TTP were a result of FY-92 carryover funds in the amount of $\$ 79 \mathrm{~K}$. FY-93 funding was not provided.

The objective of this laboratory investigation of the ice electrode was to determine the viability of using an electrode coated with a thin layer of ice in the electrolytic removal of heavy metals from waste solutions. This study focuses on developing an understanding of electrochemical behavior at the ice layer. In addition, in FY-93 a bench-scale system was designed and fabricated. This system will be used to develop the system operational envelope and economics.

\section{Accomplishments}

- Lab-scale tests determined that all plateable metals are candidates for removal from solution

- Technique can be used in dilute parts per million range solutions

- High deposition efficiency has been achieved 
- Bench-scale reactor has been designed and built.

- A informal report was issued January 1993 by D. F. Glenn and J. C. Ingram entitled Ice Electrode, EGG-WTD-10509 (see Appendix A).

\section{Technology Transfer}

Ice electrode technology will be useful for waste treatment and processes that deal with metalbearing waste solutions, including private sector mining waste streams, plating companies, and metal cleaning operations. Technology gains from treatment of DOE and Department of Defense streams will transfer readily and be of great value to a variety of private concerns.

\subsubsection{BWID Waste Form Integration and Limits-ID132006}

This TTP involves two tasks: (1) determine the waste form compositional limits within which an acceptable waste form can be produced and have the required durability and (2) provide for the integration in the following areas of BWID evaluations of pretreatment and treatment technologies: provide for standard waste form compositions, provide required INEL soil for testing, the establishment and issuing of waste form performance requirements, technology testing and evaluation, and configuration option (system) interfaces and requirements.

The main objective of Task 1 is to include composition calculations and the initiation of benchscale experiments to generate a final waste form. The main objective of Task 2 is to provide for the integration of BWID evaluations of pretreatment and treatment technologies and ensure that testing and evaluation integration will take place with other BWID treatment evaluations. Participation in the BWID Treatment Technical Support Group is also funded out of this TTP.

Accomplishments

- $\quad$ Attended BWID Technical Support Group meetings

- Participated in FY-94 Thermal Treatment Technology Selection and Evaluation

- Assisted in developing the Retrieve/Ex Situ Treatment Configuration Option

- Issued a report entitled Definition and Compositions of Standard Waste Streams for Evaluation of Buried Waste Integrated Demonstration Treatment Technologies, EGG-WTD10660, June 1993 (see Appendix A).

- Waste forms for BWID have been generated for a variety of potential waste variations, including hazardous metals. Leach testing has been completed on the slowly cooled waste forms. Results using longer-cooled samples will be completed in early FY-94.

\subsubsection{BWID Thermal Kinetics-1D132010}

This TTP funded two subtasks that support research and development efforts for the vitrification technologies being considered by BWID and Environmental Restoration at the INEL: (1) TRU 
releases during vitrification processing and (2) vapor/liquid transport phenomena during in situ vitrification (ISV).

The main objectives of these subtasks are:

\section{Subtask 1:}

To investigate the TRU release potential from the melt surface to the offgas.

\section{Subtask 2:}

Develop a fundamental understanding of liquid and vapor transport behavior in the region surrounding an ISV melt; and develop a predictive capability of the required physical and operational parameters related to transient vapor release necessary for safe ISV processing in a contaminated soil environment.

\section{Accomplishments}

- Issued an informal report entitled Modeling ISV Power Control and Lab Test Simulations Using FIDAP and VULCAN, EGG-WTD-10918 (see Appendix A).

- Issued an internal report entitled Quick Look Report on ISV Lab Test 1 Series 1, January 1993, WTD-93-052 (see Appendix A).

- Issued an informal report entitled Off Gassing Induced Tracer Release for Molten Basalt Pools, EGG-WTD-10942 (see Appendix A).

- Issued an ASTM paper entitled "Lab Test Results Supporting Resolution of the ISV Technical Issue of Vapor Transport."

- Issued an ASTM paper entitled "The Effect of Graphite Venting on ISV Processing of Low Permeability Soils."

- Completed work on phenomenological tests supporting TOUGH code development for predicting vapor transport in surrounding soils during ISV processing. Internal report due in January.

- Completed one-dimensional evaluation of TOUGH code predictive capability for vapor transport in surrounding soils during ISV processing.

\section{Technology Transfer}

Disclosure of this information through professional journals and presentations at technical conferences also will disseminate information about this technology to private sector contractors and other DOE laboratories. 


\subsubsection{BWID Arc Melter Vitrification-1D132011}

This TTP investigates the applicability of using a plasma arc furnace that pyrolyzes and combusts organic materials and melts residual inorganic materials with an electric arc for hazardous and TRU contaminated wastes.

The objective of this TTP is to demonstrate, in a currently operational commercial-scale plasma arc melter, the applicability and feasibility of existing plasma arc melter technology for high temperature treatment of TRU and mixed hazardous waste and buried or stored soils.

The arc melter could be used to treat a variety of waste containers and matrices containing both hazardous and radioactive substances. It is especially useful whenever a high efficiency destruction of organics is required. It gives a permanent encapsulation of heavy metals and radionuclides in a nonleachable final product.

\section{Accomplishments}

- The existing offgas system components can be modified for TRU surrogates and heavy metals containment.

- Approximately 20-30 metric tons of simulated waste will be processed in each melt campaign, or about 4-6 metric tons per day.

- Surrogate waste, including soils, metals combustibles, and sludges, will be prepared and separately incinerated, as appropriate, in preparation for melter processing.

- Issued an informal report entitled Test Plan for FY-93 Phase 1 Baseline Tests for the BWID Arc Melter Vitrification Project, EGG-WTD-10862, July 1993 (see Appendix A).

- Issued an informal report entitled Phase 1 Test for 3-Phase Electrical Arc Vitrification of INEL Buried Waste, EGG-WTD-10981 (see Appendix A).

\section{Technology Transfer}

University, industry, and other laboratory participants are being solicited. Because many privatesector companies are members of the present American Society of Mechanical Engineers test consortium, CRADAs with industrial partners are being sought.

\subsubsection{Butte Plasma Arc Furnace-PE021203}

Activities performed under this TTP were a result of FY-92 carryover funding in the amount of $\$ 613 \mathrm{~K}$.

The plasma centrifugal furnace (PCF) is a rotating hearth plasma torch used for refining titanium and is now being developed for treatment of hazardous and mixed wastes and contaminated soils. The PCF can treat heterogenous unconsolidated feeds including organic materials, sludges, metals, rock, concrete, soils, and other types of waste. The PCF can also be used to treat lesser 
quantities of heterogeneous nonsorted waste directly or can be used as part of an integrated waste treatment system to stabilize final waste from other treatment processes. In addition to treatment of buried mixed waste, the PCF can be used to stabilize (by vitrification) other waste that contains heavy metals and/or radionuclides such as sludges, concentrates from soil treatment, or processing residues.

The objective of this task is to demonstrate the applicability of the PCF for the treatment of mixed (hazardous or radioactive) wastes and contaminated soil into an extremely durable waste for disposal.

\section{Accomplishments}

- $\quad$ Cerium oxide (plutonium surrogate) tests were completed.

- Sludge evaluation testing was completed. This testing included high organic, sand, and clay sludges, all of which were successfully processed.

\section{Technology Transfer}

This technology is an integral component of a commercial remediation process that is proposed and being evaluated by INEL Environmental Restoration. Disclosure of this research through professional journals and presentations at technical conferences also will disseminate information about this technology to private-sector contractors that may be constructing waste-processing facilities.

\subsubsection{Graphite DC Arc Plasma Furnace-RL332016}

The objective of this TTP is to design, fabricate, demonstrate, and evaluate a graphite electrode DC arc furnace for its effectiveness in treating hazardous, radioactive (both LLW and TRU), and mixed wastes and soil, both buried and stored.

An engineering-scale furnace, the Mark I, was tested in FY-92 at the Massachusetts Institute of Technology (MIT) Plasma Fusion Center to gain preliminary information on the treatability of buried waste surrogates using DC arc technology. The Mark II furnace was designed and fabricated in FY-93, based on the results of the earlier tests. The newer design incorporates many of the features required for a semi-remote or remotely operated furnace, including prototype provisions for alpha containment and the ability to process waste continuously at power levels of more than 1 MVA and a processing rate of 500 to $700 \mathrm{lb} / \mathrm{hr}$. The Mark II furnace was designed with the capability to separate the glass phase from the metal phase.

\section{Accomplishments}

- The Mark I furnace was demonstrated and design improvements are ongoing.

- Improved diagnostics were developed that includes analytical instruments for making spatially resolved measurements of furnace and glass temperatures and online measurements of exhaust emissions, both in the furnace chamber and offgas line. 
- A pilot-scale Mark II furnace was designed and fabricated. The feed system of the Mark II melter is capable of feeding objects as large as a 35-gal drum. A full-scale system can handle limited quantities of hazardous (nonradioactive) materials. Systems capable of processing radioactive materials are being planned.

- $\quad$ A test plan was issued April 20, 1993, entitled Test Plan FY-93 Mark II Testing Treatment of Buried Waste Surrogates Using Graphite Electrode DC Arc Technology (see Appendix A).

\section{Technology Transfer}

Other commercial entities have expressed interest in both the melter and diagnostic technology. Technology transfer is occurring with the university (MIT) and industry (Electro-Pyrolysis) partners on the project. Technical progress reports and design data will be transferred to other projects, especially similar vitrification efforts.

\subsubsection{Real-Time Offgas Analysis-RL332021}

Funding for this TTP was received in the fourth quarter of FY-93. Work was initiated in FY-93, but key deliverables will not be completed until FY-94. Since this work expands on the work in TTP RL332016 (see previous TTP), Graphite DC Arc Plasma Furnace, this work will be incorporated into the other TTP for FY-94.

Nonthermal electrical discharge plasma can promote favorable chemistry for the destruction of hazardous chemicals. Electrical energy directed into the process chemistry creates highly reactive free radicals that oxidize or reduce pollutants, fragment pollutants directly, or promote excited-state chemistry.

This technology is an alternative nonincineration treatment for volatile organic destruction and metal oxidation in remediation of contaminated soil and direct mixed waste treatment. It also treats secondary waste gases from commonly used treatment processes for mixed waste such as vitrification, incineration, and thermal stripping.

The principal objective of this TTP is to evaluate the nonthermal plasma process for removal of volatile organic compounds, $\mathrm{So}_{\mathrm{x}}$ and $\mathrm{No}_{\mathrm{x}}$, hazardous compounds, and high vapor pressure metals in melter off-gases.

\section{Technology Transfer}

Other DOE sites such as Savannah River, Hanford, and Mound and participants in the industrial sector such as the chemical, electrical, production, and paper and wood product industry support technology transfer. The Electric Power Research Institute intends to cooperate with DOE on an air-toxics effort through a CRADA and technology commercialization with the private sector. 


\subsection{Programmatic}

\subsubsection{BWID Program Coordination-1D132008}

The objective of this TTP was to provide support for the general planning, coordination, and management for BWID implementation. The Program Office, referred to in Section 2, was created and organized to accomplish this task. The coordination effort funded by this TTP is a multifunctional support effort for the DOE. Specifically, tasks included in this TTP are:

1. The general BWID programmatic and technical planning, coordination, and management for implementation

2. Oversight to ensure individual BWID-sponsored technologies comply with all applicable environmental, safety, health, and quality requirements during field deployment demonstrations for technology testing and evaluation

3. Technical coordination to ensure programmatic objectives are maintained an planned into future activities of the BWID program.

\section{Accomplishments}

- Conducted FY-93 Principal Investigator Kickoff Meeting, Idaho Falls, Idaho, October 1992.

- Conducted a Technical Support Group/Program Planning Group Meeting to discuss FY-94 Needs Statements, Pleasanton, California, November 1992.

- $\quad$ Issued BWID FY-94 Needs Statements, January 1993.

- Conducted FY-93 Technical Peer Review/Program Planning Group Meeting, Denver, Colorado, February 1993.

- Conducted FY-94 Proposal Review Meeting, Idaho Falls, Idaho, May 1993.

- Conducted FY-93 Integrated Demonstration Technology Exposition and Equipment Display, June 1993.

- Conducted a Lessons Learned Exercise at Idaho State University, July 1993.

- Presented a poster at the Second International Mixed Waste Symposium, Baltimore, Maryland, August 1993.

- $\quad$ Issued FY-93 BWID Annual Report entitled Solving a National Problem, September 1993. 
- Conducted FY-94 Principal Investigator Kickoff Meeting, Idaho Falls, Idaho, September 1993.

- Issued draft of BWID Program Directives, September 1993.

- Issued various reports, checklists, and guidance documents, including Buried Waste Integrated Demonstration FY-93 Deployment Plan, EGG-WTD-10539; Facilities Evaluation Report for FY-93, EGG-WTD-10608; Buried Waste Integrated Demonstration Strategy Plan, EGG-WTD-10610; Buried Waste Integrated Demonstration Fiscal Year 1992 Close-Out Report, EGG-WTD-10612; Retrieval/Ex Situ Thermal Treatment Scoring Interaction Report, EGG-WTD-10719; and Buried Waste Integrated Demonstration Test Objectives, EGGWTD-10878 (see Appendix A).

\subsubsection{BWID Technical and Academic Review Group-1D132015}

Funding for this TTP was received late in the fourth quarter of FY-93.

The objective of this TTP is to fund the activities of the BWID Technical and Academic Review Group (TARG). The purpose of the TARG is to provide technical oversight and guidance to the BWID technology demonstration process.

Tasks included in this TTP are:

- Identify and generate functional performance requirements necessary for assessing technology effectiveness

- Define the current state-of-the-art technology in each BWID functional performance area

- Identify and prioritize technology gaps, based on system functional and technical requirements

- Characterize technology gap areas that are not being addressed by current and past BWID-funded efforts

- Provide general technical oversight and support for FY-94 BWID-funded technical demonstration projects.

Accomplishments

Contracts let for three TARG leaders.

\subsubsection{BWID/EM-40 Interface-ID132023}

Funding for this TTP was received in the fourth quarter of FY-93. Many of the deliverables will be met in FY-94. 
The objective of this TTP is to provide a vehicle for the continued exchange of information between BWID and EM-40 activities to establish a baseline of current technological capabilities for evaluation of future BWID technological advancements.

Specific tasks included in this TTP are:

- Review of INEL Pit 9 Retrieve/Ex Situ Treatment remedy bid proposals

- Assessment of proposed BWID technologies relative to EM-40 remediation plans

- Continue the joint INEL EM-40 BWID systems analysis concepts.

- Establish a stronger liaison with EM-40 through the BWID Program Planning Group to obtain additional site specific EM-40 input for technology data needs. 


\section{FINANCIAL ASSESSMENT}

Attached is the funding summary for the FY-93 BWID program (see Table 1). Data for this summary were obtained from DOE's September Financial Plan and September Progress Tracking Report. Values were validated for the INEL TTPs as of December 1993. Validation of the remaining TTPs was not possible before publication of this document.

Table 1. BWID FY-93 financial summary.

\begin{tabular}{|c|c|c|c|c|c|c|}
\hline TTP No. & TTP Title & Site & $\begin{array}{c}\text { FY-93 } \\
\text { Total } \\
\text { Funding } \\
\text { Available } \\
(\$ K)\end{array}$ & $\begin{array}{l}\text { Budgeted } \\
\text { Cost of } \\
\text { Work } \\
\text { Scheduled } \\
\text { (\$K) }\end{array}$ & $\begin{array}{l}\text { Budgeted } \\
\text { Cost of } \\
\text { Work } \\
\text { Performed } \\
\text { (\$K) }\end{array}$ & $\begin{array}{c}\text { Actual } \\
\text { Cost of } \\
\text { Work } \\
\text { Performed } \\
\text { (\$K) }\end{array}$ \\
\hline AL021201 & Gas Contamination & Albuquerque & 63 & 0 & 0 & 0 \\
\hline AL911201 & $\begin{array}{l}\text { Nonintrusive Sensing of } \\
\text { Environmentally Important } \\
\text { Objects }\end{array}$ & $\begin{array}{l}\text { Grand } \\
\text { Junction }\end{array}$ & 1,039 & 578 & 578 & 691 \\
\hline AL132012 & $\begin{array}{l}\text { Improved TRU Waste } \\
\text { Assay-CTEN }\end{array}$ & Los Alamos & 400 & 300 & 300 & 283 \\
\hline AL232006 & $\begin{array}{l}\text { Remote Characterization } \\
\text { System }\end{array}$ & Sandia & 50 & 75 & 75 & 73 \\
\hline AL232007 & Remote Excavation System & Sandia & 25 & 0 & $\mathbf{0}$ & 0 \\
\hline CH121201 & $\begin{array}{l}\text { Electrothermal Hollow } \\
\text { Cathode Discharge } \\
\text { Spectrometry }\end{array}$ & Ames & 72 & 72 & 72 & 71 \\
\hline ID121203 & Retrieval Demonstration & INEL & 622 & 702 & 600 & 579 \\
\hline ID121205 & Pad A Treatability Studies & INEL & 83 & 82 & 0 & 81 \\
\hline ID121210 & Contamination Control & INEL & 1,279 & 1,064 & 1,271 & 1,240 \\
\hline ID121211 & Ice Electrodes & INEL & 114 & 34 & 97 & 89 \\
\hline ID121212 & $\begin{array}{l}\text { Radiological and } \\
\text { Hazardous Materials } \\
\text { Measurement System }\end{array}$ & INEL & 158 & 29 & 129 & 83 \\
\hline ID 121213 & $\begin{array}{l}\text { Field Demonstration of } \\
\text { Characterization Studies }\end{array}$ & INEL & 510 & 353 & 385 & 382 \\
\hline ID132003 & $\begin{array}{l}\text { BWID Dig-Face } \\
\text { Characterization }\end{array}$ & INEL & 1,187 & 1,239 & 1,041 & 1,064 \\
\hline ID132006 & $\begin{array}{l}\text { BWID Waste Form } \\
\text { Integration and Limits }\end{array}$ & INEL & 540 & 540 & 498 & 390 \\
\hline ID132007 & $\begin{array}{l}\text { Retrieval Related } \\
\text { Technologies }\end{array}$ & INEL & 839 & 828 & 838 & 818 \\
\hline
\end{tabular}




\begin{tabular}{|c|c|c|c|c|c|c|}
\hline TTP No. & TTP Title & Site & $\begin{array}{c}\text { FY-93 } \\
\text { Total } \\
\text { Funding } \\
\text { Available } \\
\text { (\$K) }\end{array}$ & $\begin{array}{l}\text { Budgeted } \\
\text { Cost of } \\
\text { Work } \\
\text { Scheduled } \\
\text { (\$K) }\end{array}$ & $\begin{array}{l}\text { Budgeted } \\
\text { Cost of } \\
\text { Work } \\
\text { Performed } \\
\text { (\$K) }\end{array}$ & $\begin{array}{c}\text { Actual } \\
\text { Cost of } \\
\text { Work } \\
\text { Performed } \\
\text { (\$K) }\end{array}$ \\
\hline ID132008 & $\begin{array}{l}\text { BWID Program } \\
\text { Coordination }\end{array}$ & INEL & 1,960 & 1,476 & 1,547 & 1,625 \\
\hline ID132010 & BWID Thermal Kinetics & INEL & 450 & 449 & 427 & 417 \\
\hline ID132011 & $\begin{array}{l}\text { BWID Arc Melter } \\
\text { Vitrification }\end{array}$ & INEL & 650 & 650 & 636 & 380 \\
\hline ID132015 & $\begin{array}{l}\text { BWID Technical and } \\
\text { Academic Review Group }\end{array}$ & INEL & 300 & $\mathbf{0}$ & 300 & 22 \\
\hline ID132018 & $\begin{array}{l}\text { Electromagnetic Imaging } \\
\text { as Applied to Mapping and } \\
\text { Characterization of BWID }\end{array}$ & INEL & 95 & 0 & 95 & 2 \\
\hline ID132019 & Geophysical Workshop & INEL & 20 & 0 & 20 & 18 \\
\hline ID132020 & $\begin{array}{l}\text { High-Speed Digital } \\
\text { Radiography and } \\
\text { Computed Tomography of } \\
\text { Waste Drums }\end{array}$ & INEL & 457 & 0 & 26 & 26 \\
\hline ID132021 & $\begin{array}{l}\text { Hazardous and Chemical } \\
\text { Waste Separation at } \\
\text { RWMC Excavation Sites }\end{array}$ & INEL & 200 & 0 & 200 & 47 \\
\hline ID132022 & $\begin{array}{l}\text { Three-Dimensional } \\
\text { Dynamic Graphic } \\
\text { Simulation }\end{array}$ & INEL & 80 & $\mathbf{0}$ & 80 & 16 \\
\hline ID132023 & BWID EM-40 Interface & INEL & 100 & $\mathbf{0}$ & 21 & 26 \\
\hline ID132024 & $\begin{array}{l}\text { EM Rapid Geophysical } \\
\text { Surveyor }\end{array}$ & INEL & 100 & 0 & $\mathbf{0}$ & 0 \\
\hline ID032002 & $\begin{array}{l}\text { USGS/DOE-ID } \\
\text { Interagency Agreement }\end{array}$ & INEL & 235 & $\mathbf{0}$ & $\mathbf{0}$ & 175 \\
\hline ID332001 & $\begin{array}{l}\text { Remote Characterization } \\
\text { System }\end{array}$ & INEL & 289 & 290 & 311 & 277 \\
\hline ID332002 & Multi-Axis Crane & INEL & 330 & 330 & 280 & 330 \\
\hline ID332004 & Remote Excavation System & INEL & 330 & 330 & 323 & 323 \\
\hline OR132013 & $\begin{array}{l}\text { Remote Characterization } \\
\text { System }\end{array}$ & ORNL & 110 & 0 & 0 & 0 \\
\hline OR132014 & Remote Excavation System & ORNL & 245 & 0 & $\mathbf{0}$ & 0 \\
\hline PE021203 & BWID Plasma Arc Testing & PNL & 1,368 & 1,125 & 1,125 & 275 \\
\hline RL321211 & Graphite DC Arc Plasma & PNL & 1,125 & 1,988 & 1,988 & 1,188 \\
\hline
\end{tabular}




\begin{tabular}{|l|l|l|c|c|c|c||}
\hline & \multicolumn{1}{|c|}{ TTP Title } & \multicolumn{1}{|c|}{ Site } & $\begin{array}{c}\text { FY-93 } \\
\text { Total } \\
\text { Funding } \\
\text { Available } \\
\text { (\$K) }\end{array}$ & $\begin{array}{c}\text { Budgeted } \\
\text { Cost of } \\
\text { Work } \\
\text { Scheduled } \\
(\$ K)\end{array}$ & $\begin{array}{c}\text { Budgeted } \\
\text { Cost of } \\
\text { Work } \\
\text { Performed } \\
(\$ K)\end{array}$ & $\begin{array}{c}\text { Actual } \\
\text { Cost of } \\
\text { Work } \\
\text { Performed } \\
(\$ K)\end{array}$ \\
\hline RL332016 & $\begin{array}{l}\text { Remote Characterization } \\
\text { System }\end{array}$ & PNL & 190 & 190 & 190 & 187 \\
\hline RL332017 & Remote Excavation System & PNL & 25 & 25 & 25 & 24 \\
\hline RL332021 & Real-Time Offgas Analysis & PNL & 850 & 0 & 0 & 0 \\
\hline RL432002 & Fixation of Soil Surfaces & WHC & 150 & 150 & 150 & 149 \\
\hline SF221209 & $\begin{array}{l}\text { Nondestructive } \\
\text { Assay/Nondestructive } \\
\text { Examination of Low Level } \\
\text { Waste Drums }\end{array}$ & LLNL & 554 & 400 & 400 & 505 \\
\hline SF232001 & $\begin{array}{l}\text { Remote Characterization } \\
\text { System }\end{array}$ & LLNL & 95 & 95 & 95 & 95 \\
\hline SF232002 & Remote Excavation System & LLNL & 40 & 40 & 40 & 38 \\
\hline Note: Values are from September 1993 financial data. & & & & \\
\hline
\end{tabular}




\section{Appendix A}

List of Buried Waste Integrated Demonstration FY-93 Reports 


\section{Appendix A}

\section{BWID FY-93 Reports}

\section{CHARACTERIZATION}

TTP AL911201: Nonintrusive Sensing of Environmental Important Objects

DOE/ID/12584-130, Vol. 1, Preliminary Field Results, Time Domain Electromagnetic (TDEM) Survey of Three Waste Burial Pits at INEL Radioactive Waste Management Complex, January 1993, by H. David Mac Lean. Broadband electromagnetic surveys were conducted at three sites within the Radioactive Waste Management Complex at the INEL using the Geonic Limited PROTEM 47 time domain electromagnetic (TDEM) system. Chem-Nuclear Geotech, Inc., the operating contractor for the DOE Grand Junction Projects Office, performed the site surveys using the fixed-separation, moving-coil mode of operation.

Three-Dimensional Site Characterization Using Broadband Electromagnetics Technology Preparedness and Status Report, November 1992, by H. David Mac Lean. This document provided BWID program management with information to supplement the TTP in performing tests at three INEL sites of Three-Dimensional Site Characterization Using Broadband Electromagnetics.

Site Characterization and Object Location Using a Tensor Magnetic Gradiometer Research and Development Technology Status Report, November 1992, by Donald D. Snyder. This document provided BWID program management with information to supplement the TTP in performing a demonstration test of Site Characterization and Object Location Using a Tensor Magnetic Gradiometer.

TTP CH121201: Electrothermal Hollow Cathode Discharge Spectrometry

Ames Lab Report IS-5085 In-Situ Monitoring of Actinides and Rare Earth Elements by Electrothermal Hollow Cathode Discharge Spectrometry, December 1992, by Sang C. Lee and M. C. Edelson. Results from testing of electrothermal hollow cathode discharge spectrometry.

TTP ID121112: INEL Nonintrusive Characterization Studies

Letter report from South Dakota School of Mines and Technology, "Feasibility of Using Ground Probing Radar for Environmental Site Characterization: Preliminary Assessment," March 1993. This report provides an early indication of the prospects of using Ground Probing Radar for environmental site characterization at the INEL. Preliminary analyses of field measurements at the Cold Test Pit encourage the conclusion that a properly tuned and matched radar system can penetrate the soils, river sediments, and fill material at the RWMC.

Proceedings of the Ground-Probing Radar Planning Workshop (Draft), October 31, 1993. Proceedings of a planning workshop held at the Idaho National Engineering Laboratory on 
September 23, 1993, prepared by D. K. Parrish and W. M. Roggenthen of the South Dakota School of Mines and Technology. Four testing activities were recommended as having the greatest likelihood of advancing GPR technology for application to environmental restoration and waste management programs in the next 3 to 5 years.

\section{TTP ID121213: Field Demonstration of Characterization Studies}

EGG-WTD-10566 Rapid Geophysical Surveyor Final Report, January 1993. The Rapid Geophysical Surveyor is a system designed to rapidly and economically collect closely spaced geophysical data used for characterization of DOE waste sites. This report documents the design and demonstration of the Rapid Geophysical Surveyor concept, including the presentation of magnetic data collected at the Subsurface Disposal Area at the INEL. The surveys were able to show pit and trench boundaries and determine details of their spatial orientation never before achieved.

EGG-WTD-10875 Test Plan for the Rapid Geophysical Surveyor, June 1993. This document describes the test plan for demonstrating and testing a set of optically pumped cesium-based total field magnetometers using the Rapid Geophysical Surveyor platform. The testing was to assess the function of these magnetometers as deployed on the Rapid Geophysical Surveyor and evaluate the practical utility of high resolution magnetic data for supporting waste retrieval efforts.

FY-93 Rapid Geophysical Surveyor Performance Tests Final Report, August 6, 1993. The report was issued by the Applied Geosciences Unit at EG\&G Idaho by N. E. Josten and L. G. Roybal. The objectives of the work were to incorporate the total field magnetometers onto the existing Rapid Geophysical Surveyor platform and to perform quantitative characterization of the Retrieval and Characterization Cells at the INEL Cold Test Pit.

Letter report from TechniScan, Inc., "First Inverse Scattering Images from Reflection Mode," August 1993. This report describes results of work done by TechniScan, which has developed a three-dimensional scanner to demonstrate imaging of buried objects in INEL soil. The scanner is an inverse scattering GPR system producing quantitative, distortionless images analogous to a CAT system.

\section{TTP ID132003: BWID Dig-Face Characterization}

EGG-WTD-10766 Test Plan for Dig-Face Characterization Performance Testing, September 1993. A dig-face characterization system conducts continuous subsurface characterization simultaneously with retrieval of hazardous and radioactive waste from buried waste sites. The test plan describes initial efforts to test the dig-face characterization concept at the INEL Cold Test Pit using a simplificd prototype apparatus and off-the-shelf sensors. The test plan establishes procedures for collecting and validating a representative dig-face characterization data set.

EGG-WTD-10771 Dig-Face Characterization Test Plan (Remote Testing), August 1993. The objective of the dig-face characterization remote testing project is to remotely deploy a sensor head (mini-lab) across a dig-face to determine if it can characterize the contents below the 
surface. The purpose of the project is to provide a robotics technology that allows removal of workers from hazards, increases speed of operations, and reduces life cycle costs compared to alternative technologies. The purposes of the test plan are to establish test parameters so that the demonstration results are useful and performed in a safe manner.

EGG-WTD-10812 Test Plan for Prototype Dielectric Permittivity Sensor, July 1993. The dig-face characterization project funded by BWID is designed to test a new method of monitoring hazardous conditions during the remediation at waste sites. In this project, the role of a dielectric permittivity monitoring device is under investigation. This project addresses two issues: what are the optimal means of mapping dielectric permittivity contrasts and what types of targets can be detected using dielectric permittivity mapping.

EGG-WTD-10813 Test Plan for Dig-Face Chemical and Radiation Assay System, July 1993. The Dig-Face Chemical and Radiation Assay System (CRAS) project is developing a sensor using prompt gamma neutron activation analysis that can detect the presence of hazardous chemicals and radioactive materials. Tasks being performed include determining detection limits for a number of hazardous chemicals and assessing matrix and transmission effects through soil.

EGG-WTD-11044 Prototype Ground Capacitance Sensor Final Report. The dig-face project was designed to test a new method of monitoring hazardous conditions during remediation at waste sites. In this project, the role of a dielectric permittivity monitoring device was investigated. The instruments used were the high frequency sounder developed by the USGS and a time domain reflectometer.

EGG-WTD-11062 Dig-Face Characterization Development Plan. The dig-face development plan documents recommendations for development of a characterization system to be used during retrieval of buried waste. These recommendations can be used to guide system development to maximize the benefit and applicability of the system to DOE and other buried waste remediation systems.

\section{TTP ID332001: Remote Characterization System}

EGG-WTD-10596 BWID Technology Preparedness and Status Report for the Remote Characterization System, December 1992. This report was prepared to provide information on the status of both the Remote Characterization System development and the demonstration preparations. The report also assesses BWID in the integration of the Remote Characterization System into the demonstration of multiple technologies that were scheduled to take place in the summer of 1993.

EGG-WTD-10704 Remote Characterization System Test Plan, May 1993. This document describes the test plan for demonstration and testing the Remote Characterization System. The purposes of the test plan are (a) to establish test parameters to ensure that the demonstration results are deemed useful and usable, and (b) to ensure the demonstration is performed in a safe manner within all regulatory requirements. 
EGG-2691 Remote Characterization System Technology Evaluation Report, September 1993. This report describes the results for the Remote Characterization System demonstration and testing conducted at the INEL during June 1993. The demonstration showed the feasibility of an innovative remotely operated vehicle for characterizing and locating buried waste in an openair environment. 


\section{RETRIEVAL}

TTP ID121203: Retrieval Demonstration

EGG-WTD-10744 Test Plan for Retrieval Demonstration, May 1993. This test plan describes a simulated buried waste retrieval demonstration performed at the Caterpillar, Inc., Edwards Training Center located near Peoria, Ill. The purpose of the demonstration is to determine the effectiveness of using readily available excavation equipment to retrieve, size, and handle various simulated waste forms that are similar in size, structure, and composition to those expected to be found in DOE contaminated waste pits and trenches. Test objectives, detailed procedures, data quality objectives, and documentation methods are included in this plan.

EGG-WTD-10895 Full-Scale Retrieval of Simulated Buried Transuranic Waste, September 1993. This report describes the results of a field test conducted to determine the effectiveness of using conventional type construction equipment for the retrieval of buried TRU waste. A cold test pit was constructed with boxes and drums filled with simulated waste materials. During the demonstration of commercially available equipment, a number of observations, measurements, and analyses were performed to determine which equipment was the most effective in removing the waste.

\section{TTP ID121210: Contamination Control}

EGG-WTD-10360 Fugitive Dust Control Experiments Using Directed Airflow in Dumping Operations, July 1992. Experiments were conducted to evaluate the degree of dust control for using directed airflow in a funnel during dumping operations. In these experiments, the INEL soil was dumped into a full-scale funnel that was specially equipped with a directed airflow into the funnel. The degree of dust control was determined by comparing collected dust on filters in high volume samplers for a baseline case with no airflow to cases with airflow.

EGG-WTD-10717 Test Plan for the Field Evaluation and Demonstration of the Contamination Control Unit, June 1993. This document describes the test details of the full demonstration of the CCU, a mobile trailer capable of employing the use of soil fixatives, dust suppression agents, misting, and vacuum systems. Test objectives, detailed experimental procedures, and data quality objectives necessary to perform the field demonstration are included in this test plan.

EGG-WTD-10758 Test Plan for Demonstration of Rapid Transuranic Monitoring Laboratory, June 1993. This plan describes tests to demonstrate the capability of the RTML to monitor airborne alpha-emitting radionuclides and analyze soil, smear, and filter samples for alpha- and gamma-emitting radionuclides under field conditions. Measurement systems installed in the lab that were to be demonstrated include two large-area ionization chamber alpha spectrometers, an X-ray/gamma-ray spectrometer, and four alpha CAMs. Test objectives, requirements for data quality, experimental apparatus and procedures, and safety and logistics issues are described.

EGG-WTD-10886 Contamination Control Unit Operations Manual, September 1993. This operations manual provides detailed procedures and instructions for deployment of the EG\&G Idaho, Inc., CCU. The unit is a mobile trailer housing equipment that supports four 
contamination control systems: water misting, dust suppression application, soil fixative application, and vacuuming operations.

EGG-WTD-10898 Operating Procedures for Rapid Transuranic Monitoring Laboratory, October 1993. Procedures to collect, prepare, and analyze soil, smear, and air filter samples for alphaand gamma-emitting isotopes using instrumentation installed in the RTML are described. Procedures for moving and setting up the lab sample preparation and analysis trailers are also described. Detailed operating procedures for the three measurement systems are presented.

EGG-WTD-10935 Field Test of the Rapid Transuranic Monitoring Laboratory, December 1993. A field test of the RTML was conducted as part of a demonstration sponsored by BWID. Objectives, experimental procedures, and an evaluation of the performance of the lab are presented.

EGG-WTD-10973 Evaluation of the Contamination Control Unit During Simulated Transuranic Waste Retrieval, November 1993. This report presents the results of the field demonstration at the INEL of the CCU, a field deployable self-contained trailer-mounted system to control contamination spread at the site of TRU handling operations. Assessment of the unit involved laboratory operational performance testing, operational testing and contamination control at a decommissioned INEL reactor, and field testing in conjunction with a simulated TRU buried waste retrieval effort at the Cold Test Pit.

\section{TTP ID132007 Retrieval Related Technologies}

EGG-WTD-10450 Preconceptual Design for the Electrostatic Enclosure, September 1992. This report presents a preconceptual design for electrostatic enclosures to be used during buried TRU waste recovery operations. In addition to the conceptual design, engineering-scale tests are proposed to be run at TRA.

EGG-WTD-10635 Test Plan for Engineering-Scale Electrostatic Enclosure Demonstration. This test plan describes experimental details of an engineering-scale electrostatic enclosure demonstration to be performed at the INEL in FY-93. This demonstration was to investigate the feasibility of using electrostatic enclosures and devices to control the spread of contaminants during TRU waste handling operations.

EGG-WTD-10716 Test Plan for the Overburden Removal Demonstration, June 1993. This document describes the test plan for demonstration and testing of equipment performance and techniques for removal of overburden soil, control of contamination spread, and dust control. This test plan describes the objectives of the demonstration, data quality objectives, methods to be used to operate the equipment and use the techniques in the test area, and methods to be used in collecting data during the demonstration.

EGG-WTD-10767 Removal of Overburden Soils from Buried Waste Sites, October 1993. This report describes the results of a field demonstration conducted to evaluate a technology for removing overburden soils at the RWMC Subsurface Disposal Area at the INEL. The full-scale demonstration conducted at the INEL Cold Test Pit evaluated equipment performance and techniques. Personnel took air particulate samples, physical measurements of the soil cuts, 
maneuverability measurements, and rate of soil removal data. The report discusses the results of the analysis of the precision and accuracy, contamination, and dust control.

EGG-WTD-10780 Evaluation of Steel Sheet Pilings to Create Vertical Retaining Walls During Buried Waste Retrieval, September 1993. This document presents a study of using vertical retaining walls in the form of steel sheet piles for use during buried TRU waste retrieval. The report includes (a) an evaluation of various sheet piling systems and anchoring techniques, (b) evaluation of a specific concept for use at the INEL and general concepts for the Hanford Site and ORNL, (c) assessment of the permeability to external groundwater, and (d) design basis accident calculation for static, wind, earthquake, snow, and hydrostatic loads for the INEL concept.

EGG-WTD-10988 Engineering-Scale Electrostatic Enclosure Demonstration, September 1993. This report presents results from an engineering-scale electrostatic enclosure demonstration test. This electrostatic enclosure is part of an overall in-depth contamination control strategy for TRU waste recovery operations.

\section{TTP ID132008: BWID Regulatory Coordination}

EGG-WTD-10651 INEL Operable Unit 7-13 Containment and Stabilization Configuration Option, May 1993. A containment and stabilization configuration option has been developed for the INEL's Subsurface Disposal Area Operable Unit 7-13, the TRU-contaminated waste pits and trenches. The configuration option is presented as an end-to-end system block diagram.

EGG-WTD-10931 End-Effectors and Attachments for Buried Waste Excavation Equipment, September 1993. This report presents a literature search of the state of the art in end-effectors and attachments in support of excavation of buried TRU waste. Included in the report are excavator platforms and a discussion of the various attachments. Also included is a list of vendors and specifications.

\section{TTP ID332002: Multi-Axis Crane}

WTD-92-051 Buried Waste Integrated Demonstration Technology Status Report for the Multi-Axis Crane (WTD-92-051), November 1192, by K. M. Croft. An internal report for the evaluation of the preparedness and status of the remote control Multi-Axis Crane demonstration.

Letter report (BEG-04-94) to Aran T. Armstrong, DOE-ID Operations Office, January 24, 1994. The report details the modifications made to the Multi-Axis Crane, the tests that were conducted, and the results. The Multi-Axis Crane was converted from a manually controlled device to a robotic system.

TTP ID332004: BWID Remote Excavation System

EGG-WTD-10599 Technology Preparedness and Status Report for the Remote Excavation System, December 1992. The report was prepared to provide information on the status of both the RES development and the demonstration preparations. The report also assisted BWID in 
the integration of the RES into the demonstration of multiple technologies during the summer of 1993.

EGG-WTD-10703 Remote Excavation System Test Plan, May 1993. This document describes the planned tests for the Remote Excavation System demonstration for BWID. The purposes of the test plan are (a) to establish test parameters to ensure that the demonstration results are deemed useful and usable, and (b) to demonstrate performance in a safe manner within all regulatory requirements.

EGG-2710 Remote Excavation System Technology Evaluation Report, September 1993. This document describes the results of the Remote Excavation System demonstration and testing conducted at the INEL during June and July 1993. The purpose of the demonstration was to ascertain the feasibility of the system for skimming soil and removing various types of buried waste, and to compare the performances of manual and remote operation of a backhoe.

TTP ID33204: BWID Remote Excavation System Demonstration

EGG-WTD-10599 BWID Technology Preparedness and Status Report for the Remote Excavation System, December 1992. This technology and status report was prepared to provide information on the status of both the Remote Excavation System development and the demonstration preparations. The report also assisted BWID in the integration of the Remote Excavation System into the demonstration of multiple technologies scheduled for the summer of 1993.

\section{TTP RL432002: Fixation of Soil Surface Contamination Using Natural Polysaccharides}

WHC-EP-0688 Fixation of Soil Surface Contamination Using Natural Polysaccharides, September 1993, by M. R. Sackschewsky, published by Westinghouse Hanford Company. Natural polysaccharides were evaluated as alternatives to commercially available dust-control agents for application in buried waste and contaminated soil remediation situations. The two products evaluated were pregelled potato starch and a mixture of carbohydrates derived from sugar beets. 


\section{TREATMENT}

TTP ID121205: Pad A Treatability Study

EGG-WTD-10640 Laboratory-Scale Vitrification of Low-Level Radioactive Nitrate Salts and Soils from the Idaho National Engineering Laboratory, July 1993. The INEL has radiologically contaminated nitrate salt and soil waste stored aboveground and belowground at Pad A and the Acid Pit at the RWMC. Laboratory-scale melting of actual radionuclides containing INEL Pad A nitrate salts and Acid Pit soils was performed. The salt/soil/additive ratios were varied to determine the range of glass compositions; maximize mass and volume reduction, durability, and immobilization of hazardous and radioactive metals; and minimize viscosity and offgas generation for wastes prevalent at the INEL and other DOE sites.

\section{TTP ID132006: BWID Waste Form Integration and Limits}

EGG-WTD-10660 Definition and Compositions of Standard Wastestreams for Evaluation of Buried Waste Integrated Demonstration Treatment Technologies, June 1993. This report established a set of standard wastestream compositions to be used by BWID to evaluate the emerging technologies. Five wastestreams were proposed that use four types of waste and a nominal case that is a homogenized combination of the four wastes.

\section{TTP ID132010: BWID Thermal Kinetics}

WTD-93-052 Quick Look Report on ISV Lab Test 1 Series 1, January 1993. Three ISV Lab tests were performed in November and December of 1992 as part of the ISV Lab Test Series 1. The primary purpose of the test series was to provide processing and analytical data useful in the development and validation of both the VULCAN and TOUGH codes. The purpose of this report is to report on some of the conclusions generated from a preliminary look at the data resulting from these tests.

EGG-WTD-10942 Off Gassing Induced Tracer Release for Molten Basalt Pools. An in situ vitrification testing program has been conducted at the INEL to assess in situ vitrification suitability for long-term stabilization of buried radioactive waste and contaminated soil. To access process suitability and overall technical issues, two intermediate field tests were conducted at the INEL. This report assesses the gas generation phenomena that could explain differences in tracer release behavior in the two tests.

EGG-WTD-10918, Modeling ISV Power Control and Lab Test Simulations Using FIDAP and $V U L C A N$. November 1993. Numerical studies of heat and melting in soil are presented in this report. The commercial finite element code FIDAP is used to model a two-dimensional ISV system. The VULCAN computer code is used to model the three-dimensional experiment. 


\section{TTP ID132011: BWID Arc Melter Vitrification}

EGG-WTD-10862 Test Plan for FY-93 Phase 1 Baseline Tests for the BWID Arc Melter Vitrification Project, July 1993. Electric arc melter baseline tests were to be performed at the U.S. Bureau of Mines Albany Research Center and were part of the Phase 1 of the BWID arc melter vitrification project. A series of five baseline tests were to be conducted, one each for five different surrogate waste mixtures. The baseline test program includes testing each waste type at a feed rate of up to $1,500 \mathrm{lb} / \mathrm{h}$ while performing a number of diagnostic measurements to determine the fate of the feed constituents and monitoring the performance of the feeder, melter furnace, process control, tapping, and offgas control system subsystems.

EGG-WTD-10981 Phase 1 Baseline Test for 3-Phase Electrical Arc Vitrification of INEL Buried Waste. This report presents field results and raw data from the BWID arc melter vitrification program Phase 1 baseline test series conducted by the INEL in cooperation with the U.S. Bureau of Mines. Five different surrogate waste feed mixtures were tested that simulated thermally oxidized, buried, TRU-contaminated, mixed wastes and soils present at the INEL.

\section{TTP RL332016: Graphite DC Arc Plasma Furnace}

Test Plan FY-93 Mark II Testing Treatment of Buried Waste Surrogates Using Graphite Electrode DC Arc Technology, April 20, 1993. This document was prepared by Pacific Northwest Laboratory, Massachusetts Institute of Technology, and Electro-Pyrolysis, Inc. The objective of the work was to determine the suitability of the graphite electrode DC arc process to the treatment of INEL buried wastes, and to evaluate the capability of the Mark II system. 


\section{PROGRAMMATIC}

\section{TTP ID132008: BWID Regulatory Coordination}

EGG-WTD-10539 Buried Waste Integrated Demonstration FY-93 Deployment Plan, February 1993. This document is the basic operational planning document for BWID deployment of the seven INEL field demonstrations. Additional sections deal briefly with four non-INEL field and laboratory demonstrations and with four INEL laboratory demonstrations.

EGG-WTD-10608 Facilities Evaluation Report for FY-93. Twenty-three TTPs were identified to support this mission during FY-92; ten of these identified some support requirements when demonstrations were to took place. This report describes the tasks supported by BWID, the support requirements requested by the principal investigators, and an evaluation of INEL facilities that could be considered for use in the BWID technology demonstrations.

EGG-WTD-10610 Buried Waste Integrated Demonstration Strategy Plan, February 1993. Longand short-term strategies of BWID are provided. Processes for identifying technological needs, screening candidate technologies for BWID applicability, researching technical issues, field demonstrating technologies, evaluating demonstration results to determine each technology's threshold of capability, and commercializing successfully demonstrated technologies for implementation for environmental restoration also are presented in this report.

EGG-WTD-10612 Buried Waste Integrated Demonstration Fiscal Year 1992 Close-Out Report, February 1993. This report summarizes the activities of the BWID program during FY-92. It summarizes the management approach; technical accomplishments in the areas of characterization, retrieval, treatment, and programmatic; and financial management.

EGG-WTD-10719 Retrieval/Ex Situ Thermal Treatment Scoring Interaction Report, November 1993. A retrieval/ex situ thermal treatment technology process option for the INEL TRU waste pits and trenches is presented. A system performance score is calculated, and assumptions, requirements, and reference baseline technologies for all subelements are included.

EGG-WTD-10878 Buried Waste Integrated Demonstration Test Objectives, May 1993. The document provides the test objectives against which the BWID demonstrations were to be tested during FY-93. It provides the overall objectives for the core system, subelement test objectives, and technical test objectives for each technology that will be demonstrated.

Solving a National Problem, FY-93 BWID Annual Report, September 1993. This document describes the FY-93 BWID program effort for remediating waste sites. It describes each of the various project's objectives, accomplishments, and benefits. 
Appendix B

\author{
List of FY-93 Subcontractors \\ (Private Industry, Universities, \\ and Other Non-DOE Federal Agencies)
}



. 


\begin{tabular}{|c|c|c|c|c|c|}
\hline \multicolumn{6}{|c|}{ Buried Maste Integrated Demonstration FY-93 Mon-DOE Partnerships } \\
\hline TTP, Tit le & Contractor & State & Products, Services & $\$$ & Vehicle \\
\hline $\begin{array}{l}\text { ID121210, Contamination } \\
\text { Control }\end{array}$ & Boots and Coots & & Contamination Control Unit equipment & $25 \mathrm{~K}$ & $\begin{array}{l}\text { Bid/Purchase } \\
\text { Order/EG\&G }\end{array}$ \\
\hline $\begin{array}{l}\text { ID121203, Retrieva } 1 \\
\text { Demonstration }\end{array}$ & Caterpillar & IL & $\begin{array}{l}\text { Retrieval demonstration, Cold Test Pit } \\
\text { construction, equipment development }\end{array}$ & $250 \mathrm{~K}$ & Subcont. /EG\&G \\
\hline $\begin{array}{l}\text { ID111202, In Situ } \\
\text { Vitrification Research } \\
\text { and Development }\end{array}$ & Environmental Sciences, Inc. & MM & $\begin{array}{l}\text { Modeling/vapor transport around in situ } \\
\text { vitrification melt }\end{array}$ & $50 \mathrm{~K}$ & Subcont. /EG\&G \\
\hline $\begin{array}{l}\text { ID332002, Multi-Axis } \\
\text { Crane }\end{array}$ & Cimetrix, Inc. & UT & Controller deve lopment & $73 \mathrm{~K}$ & Subcont./EG\&G \\
\hline $\begin{array}{l}\text { RL321211, Graphite DC Arc } \\
\text { Plasma Furnace }\end{array}$ & Electro Pyrolysis, Inc. & $\mathrm{PA}$ & Furnace deve lopment and testing & $200 \mathrm{~K}$ & Subcont./EG\&G \\
\hline $\begin{array}{l}\text { ID132007, Retrieval } \\
\text { Related Technologies }\end{array}$ & Sonsub & $T X$ & Overburden removal/waste isolation & $345 K$ & Subcont./EG\&G \\
\hline $\begin{array}{l}\text { ID121213, Field } \\
\text { Demonstration of } \\
\text { Characterization } \\
\text { Technologies }\end{array}$ & TechniScan & UT & $\begin{array}{l}\text { Apply geophysics data to a proprietary } \\
\text { logarithm }\end{array}$ & $260 \mathrm{~K}$ & Subcont./EG\&G \\
\hline $\begin{array}{l}\text { ID121210, Contamination } \\
\text { Control }\end{array}$ & Wells Cargo & ID & Contamination Control Unit equipment & $13 K$ & $\begin{array}{l}\text { Bid/Purchase } \\
\text { Order/EG\&G }\end{array}$ \\
\hline $\begin{array}{l}\text { I0121210. Contamination } \\
\text { Control }\end{array}$ & ITRI & MM & Evaluating surrogates for $\mathrm{Pu}$ & $70 K$ & $\begin{array}{l}\text { MPO/EG\&G to } \\
\text { ITRI }\end{array}$ \\
\hline $\begin{array}{l}\text { ID132003, BWID Dig-Face } \\
\text { Characterization }\end{array}$ & Ecology Internationa 7 & CO & Consulting, dig-face data interpretations & $60 \mathrm{~K}$ & Subcont./EG\&G \\
\hline \multicolumn{6}{|l|}{ UNIVERSITIES } \\
\hline $\begin{array}{l}\text { RL021202, Vitrification } \\
\text { of Mixed TRU and LLW }\end{array}$ & Purdue University & IN & Study of dissolution of metal in glass & $30 \mathrm{~K}$ & Subcont./PNL \\
\hline $\begin{array}{l}\text { RL321211, Graphite DC ArC } \\
\text { Plasma Furnace }\end{array}$ & $\begin{array}{l}\text { Massachusetts Institute of } \\
\text { Technology }\end{array}$ & MA & Furnace testing and analys is & $250 \mathrm{~K}$ & Subcont./PNL \\
\hline
\end{tabular}




\begin{tabular}{|c|c|c|c|c|c|}
\hline \multicolumn{6}{|c|}{ Buried Waste Integrated Demonstration FY-93 Mon-DOE Partnerships } \\
\hline TTP, Title & Contractor & State & Products, Services & $\$$ & Vehicle \\
\hline $\begin{array}{l}\text { ID121112, Non intrusive } \\
\text { Characterizat ion Studies }\end{array}$ & South Dakota School of Mines & SD & $\begin{array}{l}\text { Factors affect ing ground-penetrating radar } \\
\text { performance at the INEL }\end{array}$ & $67 K$ & Subcont./EG\&G \\
\hline $\begin{array}{l}\text { ID132008, BWID Regulatory } \\
\text { Coordinat ion }\end{array}$ & Colorado School of Mines & $\mathrm{CO}$ & Retrieval Technical Support Group & $60 K$ & Subcont./EG\&G \\
\hline \multicolumn{6}{|l|}{ OTHER FEDERAL AGENCIES } \\
\hline $\begin{array}{l}\text { ID121112, Non intrusive } \\
\text { Characterizat ion Studies }\end{array}$ & U.S. Geological Survey & $\mathrm{CO}$ & $\begin{array}{l}\text { Interpretation of a irborne geophysical data } \\
\text { sets; geophysical support tasks }\end{array}$ & $300 \mathrm{~K}$ & $\begin{array}{l}\text { DOE-ID to } \\
\text { GJPO }\end{array}$ \\
\hline $\begin{array}{l}\text { ID132011, Arc Melter } \\
\text { Vitrification }\end{array}$ & U.S. Bureau of Mines & OR & Furnace testing and analysis & $250 \mathrm{~K}$ & $\begin{array}{l}\text { MPO/DOE-ID to } \\
\text { USBM }\end{array}$ \\
\hline
\end{tabular}

